University of Rhode Island

DigitalCommons@URI

Open Access Master's Theses

1952

\title{
The American Policy of Collective Security Through The United Nations as Expressed in the Korean Action
}

Frank Ohler Leighton

University of Rhode Island

Follow this and additional works at: https://digitalcommons.uri.edu/theses

\section{Recommended Citation}

Leighton, Frank Ohler, "The American Policy of Collective Security Through The United Nations as Expressed in the Korean Action" (1952). Open Access Master's Theses. Paper 1803.

https://digitalcommons.uri.edu/theses/1803

This Thesis is brought to you for free and open access by DigitalCommons@URI. It has been accepted for inclusion in Open Access Master's Theses by an authorized administrator of DigitalCommons@URI. For more information, please contact digitalcommons-group@uri.edu. 
THE AMERICAR POLICY OP COLLECTIVE SECURITY

THROUGR THE UNITED WATIONS AS EXPRESSED

III THE KOREAN ACTION

By

Prank Ohler Lelghton

A THESIS SUBUITTED IN PARTIAL PULPILLMEIT OP THE REQUIREMISNTS FOR THE DEGREE

OF

UASTBR OF ARTS IN HISTORY

ORIVRRSITY OF RHODE ISLAKD

1952 


\section{ABSTRACT}

The purpose of thla lngiliry has been to subject to a eritical analysis the American pelieg of collective socurity as exprossed in the Korean act10n, in order to dotermine how that polley has been expressed in a signirleant international 1adue. The writer has appromehed the problew es citigen of world commulty componed of national states plodgod to the taak of managing that community for the common good.

It has been the writer's alm to present a study of the developing polley of the United States in regard to colloctive securlty within the framework of current inter-" national developments. An extensive study of the offlcial records of the United Nations has been made in order to looate primary material which might servo as the basis for historical evaluation. The main body of the thesis has been developed from those records. Portions of the peeches of the delegates or sumaries of them which preserve as much of the flavor of the delegates' statementa as possiblo are fren quentiy cited. .

In addition to the official records of the Onited Nations, the records of the San Francisco Conference have been examined at length in order to ascertain the intentions of the signatories to the United Nations Charter and to servo as gulde in interpreting the Charter. Signiflcant oxpressions 
of Anerican policy have beon efted from the San Francisco Conference, from questions considered before the security Councll prior to the Korean action, and from the evolution of the American position with rospect to Korea. The major elements of positions hold by other states have been included where necessury, in order to exalno the American position wthin the overall context of the partioular sssue in question.

The results of the atudy peen to indicate some major Gevelopments in the American policy of oollective security through the United Nat1ona. Firet, the United states no longer places the egree of truat in the unanimity prinelple whlch it held at San Franc1sco. Tho study of the development of American polley in the Unlted Nations prior to the outbreak of host111ties Indicated a persiatent movement by the United States away from the position it had held at San Frane1sod.

Second, the Korean action marked the complete breakdown of great power unlty as the sole means of supplying effoctive oollective measures with wich to implement a polloy of collective security. The United Statios and other members of the United Nations were forced to devolop improvisatione in order to cope with the Korean problem.

Talrd, consideration of the Eorean problem has led to the developwent of a new Intexpretation of the Charber as witnessed in the "Uniting for Peace" resolution. For the first time, the United States has been willing to allow the ceneral 
Assombly to participate, if necescary, In recomendations for enforcement measures.

Last, the United States has demonetrated that it viows Its national interests as vitally afrected by the welfare of the Unttod Nations. 
TABLE OF CONTENTS

Cha pter

Page

I. INTRODUCTIOR $\ldots \ldots \ldots$

II. COLLECIIVE SEOURITY: PHE EVOLUPION OF AMERICAN POLICY IN SEVEN QUESTIONS CONSIDERED BY THE SECURIII COUNCIL OF PHE UNITED RATIONS . . . .

A Comparison of Certain Characteristics of the United Nations and the League of Nat1 ons

The Procedure for Hiendling International Disputes Culminating in of Iikely to Culmina te in Armed confliot

The United States' Definition of "Threat to the Peace"

The Position of the United States on the Implementation of anitod Nations Collective Security Poller and the veto

American Polloy by 1950 on chapters V, VI, and VII of the Charter

III. THE BACKGROUND OF THE KOREAN PROBLEA, 1945-1850 - 15 Koree"s Historleal "Independenoe"

Al11ed Agreements, 1945

Deadlock of the Joint Commilesion

Korea Before the General Aasembly

Onited Nat1ons Temporary Commiselon on Korea

The Interim Comittee

The Formation of Two Rival Governments in Korea The Fithdrawal of Ocoupation Forees

The Commission's Conclusions of July, 1949

The Renewal of the Commission, Oetober 21, 1949 
IV. ARUED GONPLICT IH KOREA AHD THE APPEASS FOR COLLECTIVE ACTION: THE RESOLUTIONS OF JUNE 25

AND JUNE 27, $1950 \ldots \ldots$

The Composition of the security coundil from January unt11 August, 1950

The June 25 Resolution

Recomendations of the Unt ted Nations Conmission on Rorea

The Americen Position of June 27

The Position of Yugesiavia

Other Att1tudes Ixpressed in the Security Couno11.

The Positions of Egspt and India

The Position of the U.S.S.R, and other Communt st Countries

American Polley on the Use of Ammed Foree to Restore Peade in Korea

V. FURTHER DEVELOPMEITSS IN THE KOREAN ACTION AID

THE INTERVENTION OF THE PEOPEE'S REPUBIIC OF

CHINA

American Intervention in Korea and Communtst Rea ctions to the June 27 Resoluti on

The offer of Chinese Natione 11st Troops for Korea

Continuation of the Conflict in Korea

The July 7 Resolution: the Recommendation for Unifled Command under the United States

The Unifled Comand in Operation

The Return of the U.S.S.R, to the Security Couno11, August 1, 1950

W11tary Ao.tivities in Korea Retreat and Counter offensive

The Intervention of the People's Republie of chlna 
V. THE AMERICAN VIBN OPPOSED: THE POSITIONS OF THE PEOELP'S REPUBLIC OF CHINA AMD THE U.S.S.R. .

The Invitation to the Peeple's Republis of China to

The combination of the Two questions: "Corplaint of Amod Invasion of Triman (Formosa)" and "Complaint of Aggression upon the Repubile of Korea"

The Position of the People's Republia of China

The Position of the U.S.S.R.

VIT. LEOAI ASPECTS OF THE KOREAN ACTION ....... 74

Pre-crisis Internationa 1 Agreements Concorning Kores

The Formation of Two States: North Korea and South Koree

Status of the People's Repubile of China

The Status of Formean

The Intervention of the Peoplets Republic of Chine In the Korean War

Collective Securl ty Theough the United Nations: Enforcement Hearures Agreed ipon at San Prancisoo

The Resort to Improvised Seourlty Arrangements as Result of the Pellure to Aohleve Great Power Unity

The Korean Action An Effective Collectlve Heasure under Article 2 of the Cherter

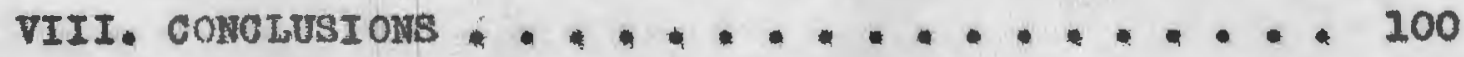

M11 tary Pressure Wight Be Neoessary in

Order to Implement a Polley of Collective securt by

Distinetions Between the Korean Aetion and Previous Questions Considered by the Seourity councll 
The Umanimity Prinotplo and Security Counc1 I Aetion

The EfPorts of the Unt ted Stetes to Incresse the Powers of the Ceneral

Assembly

The Korean Aetion as a Focal Polnt for the Formulation of an Effective Polloy of colloctivo Seoumity 


\section{CHAPTER I}

\section{INTRODUCTIOH}

From the earliest times of recorded history the attompts of human belinge to erect struatures to preserve poace heve beon witnessed and passed on to sueceoding generations. The League system developed by Athensm-and exploited by that ancient democracy in woh a way as to produce 1 ts own ruin-gave way to the Pax flomana of the Romen Fuplae. With the collapse of the Roman Emp1re, I1ttle organization to preserve peace was foasible, and warfare in the Mlddle Agos was notod for lts aavagery and lack of humanttarian rules.

Wth the Refomation, the 1dea of universel papal supremacy was deatroyed, and the sise of national states was ravored. As these national states contended with one anothor to advance themselves or mitual intereata, eonoepts of international organization adranced with thom. The British Implro, with 1te balanes of power aystom, emerged in the nineteenth century as the strongest inglo nation capablo of proventing a major world conflagration. Great Britain managed to proserve a falr degree of harmony in the world bJ adroltis ohiftIng her power to fevor one side or another at the opportune momont.

Mations (Mow York, 1950), $\frac{\text { A Conelee Historr of the Lew of }}{35}$


Early in the twentieth century the balance of power system broke down and the result was the Pirst World War. The entrance of the United States into the European confliet tlpped the balance in favor of the All1es and paved the way for the ereation of the Loague of Hetions. After the war was over, the American poople were not as willing as Prosident Wilson to depart from the polley of 1 solation the had followed since the tiwe of Washington'a Farewell Address. The United States attempted to avold responsib111ty in International affalrs and pursued her own national interests of th 11ttlo regard for the effects which her policles migh have on other nations or the stability of world peace. In the meantime, the League of Vatione struggled desperately to achleve some means of preventing armed conflicts between nations, but was powerless to enforce 1 ts will agalnst a major powar.

The tremendous destruction brought about by the Second World War, which followed so close to that of the first, convineed the overwhelming majority of Amerlcans that the time pad come to cast loose from the doctrine of 1solat1on and to venture forth to create some lasting organization for the preservation of internationel peace. On Detober 24, 1945, the American people bound themselves to a now experiment in government. On that daj, Seoretary of State James F. Byrnes algned and published the protocol of 
deposit of ratifications of the United rations charter in 1 bohalf of the American people.

The objectives of this study w111 be to examine the manner in which the United States has expressed her pol10J of olleotive security in seven pelected questions considered by the United Hations prior to the Korean action, and to ondearor to determine how that polley has been modifled op dorelopod by the Korean action. Wh method used in the Inquiry $\mathbf{w 1 1}$ be to present miterial taken from the orfetil rocorda of the United Hat1ons and other sources, in ordir deteraine signifloant expresions of Americen policy within the ecatext of the particular lesue or 1ssues involved. Proj the material presented the writer w111 offer an interpretation of the developlag Amerioan polloy and the potatbil Ignifleance of the 18 sues brought forth in the development of collective securlty through the Dnited Netione. 
CHAPTER II

COLIECTIVE SECURITY: THE EVOLUTION OF AMERICAX POLIOY IN SEVEX QUESTIONS CONSIDERED BY THE SECURIFY COUICIL OF THE UHITED MATIOIS

A Comparison of Certain Characteristics of the United Nations and the Leasue or Mations

As the nations of the world appronched thelr socond attempt in the twentieth century at International government, questions were ralsed as to the extent of authority to be delegated to the United rations. The League of Mations had boen based upon the striet soverelgety of national states and requlred unanimity among the member states to obtain consent for action. The United rations Charter was drafted during the second World War, whon the effoctiveness of unanimity among the grazt fuwero acting tegether to suppress the milltant expansion of the Ax1s was clearly apparent. Desiring to retain this Instrument of colloetive socurlty, the five great powers Insiated upon, and were accorded, permanent seats on the now Security Council; and each power was permitted to frustrate Security Council recomendations and ordera by moans of a negative vote.

since the Charter conforred "primary responsibility for the malntenance of International peace and security" on the socur1ty Counc1l and ondowed 1t with onforcement powers 
1

of a military nature, the Un1ted Nations clearly sooms to have been deslgned to be capable of enforeling 1 tg will upon offending states of lesser rank. It remained to be seen whother the Charter would be at all adequate as an instrument of collective security if the great powers should quarrel among themselves. By the same token, it remained to be seen whether the United lations would grow so much in power and authority, through strong leadership and Chartor interpretat1on, as to become evontually a uprenational authority.

Was It to become endowed with an authority superior to that of the sovereign nations; or was it an orgenization acting as an agent of soverol mations, and, hence, incepable of going beyond the wishes of any one of 1 ts great power prinelpals? The Unitod statos vould have a major part in the outcome. The polley of the United States as Indleated during seven cases consldered by the security Coune1l from 2946 to 1950 will be analjeed in an ondeavor to ascertain how the United States as a member state has expressed her views in regard to the problem of collective security through the United Nations.

\footnotetext{
Charter of the United Nat1ons, chap. VII, par. 39-51. 2

The seren cases selected are: the Iranian, Greek, and Indonesian questions, the Corfu Channol Incidepts, and the Palostine, India-Pakistan, and Berlin questions.
} 
The Procedure for Hendling International D1sputes Culminating in or Likely to Culminate

In Armed Conflict

The United States has contributed a groat doal to the development of an orderly prooedure within the United Nations to cope with international disputes loading to armed confllet. Proceeding from the Iranian question in 1946 to the developments of the India-Pakistan question to 1950, a rather consistent evolution in procedure has taken place in which the United States has boen the principal designor. The United States has contributed mainly by the resolutions which she has drafted, those to which she has lent hor support, and those against hich sho has used her vote and Influence. Ernost Gross summarized this procedure during Pobruary, 1950, while spoaking before the security 1

Council on the India-Pakistan question. Drawing on the experience of the Renville Agreement in the Indonesian case and the experience of the armatice agreements in the Palestine case, ho stated the American position. The mothod outlined by Gross was composed of throe main steps: elimination of military pressure, supervision by the Unitod flations, and the attainment of lasting political solution. This procedure almed first at eliminating the "military pressure" botween the two partios. The olimination of

1

United Nations Securlty Gounoll officlal Records, 5 th Yr., 467 th Meeting, 24 February 1950, No. 9, pp. 12-18. Hereafter reforred to as U. M. 3 . C. off. Rec. 
this pressure was to be regarded as a "atop-gap measure" only. It was to serve as a means of bringing about a more favorable atmosphere, freer of tonsion, in order that the parties in dispute might be able to arrive at a more lasting political settlement--and thus remove the differences from the realm of armed confilct. This settlement was to be made under the "aegis" of the socurity Council, as warren Austin had poeomended oarlier in the India-Paklatan question.

The second part of the process concerned the amount of Initiative the United Nations Security Counc1l was to take. According to the Amerlcan position, the Security Counc1l was to be froe to atop in, 1f nocessary, while "the - frectuation of a coase-fire and demilitarization program was in process." ${ }^{2}$ Farly in the India-Pakistan case, Philip Jossup maintained that the subsidiary organs of the Securlty Councll should be endowed with broad powers and reapons1bility, and that the council should plaoe great reliance on these subsidiary organs or individuals performing a imilar task.

The last phase of the solution of the problom lay in attalning the lasting polltical solution. Fere the American

U.N.S.C. Off. Rec., 3rd Yr., 235th Heetings.

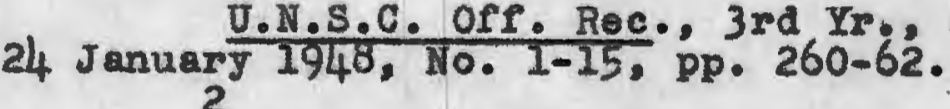
Ibld., 5th Yr., 467 th Wooting, 24 Fobruary 1950, No. 9. pp. $12-18$. 3

Ho. 127, p. 9 . 
position of placing that reponsibility upon the parties to the dispute has boon a dfficult one to imploment. Although the American position vithin the United Hations has generally followed the sincere efforts of 1 ts delegates to pursue a polley deducod from such a promise, the present day realitios of international politics have introduced anothor element. Any appraisal of the effectiveness of a colleotive security polley pursued under the aegls of the United-Natione 1. subjoct to the complication introduced by the inequelity of the Influence oxerted by the great powers in an international commity of allegedly "equal" atates. Thus, in the Palestine case, the sudden de facto recognition of the State of Israel by President Truman doubtless acted as a strong factor in determining the eventuel political solution (even though one of the parties to the dispute was strongly against just the solution this action fostered--partition and the recognition of Iarael as an independent state). A similar instanoe of having to differentiate botween the effectiveness of United Nations moasures as Unitod Nations measures and measures adhered to because of the influence

\section{1}

F. Lee Benns, Europe Since 1914 in 1 ts World Setting (7th od.; Now York, 1949), p. 744. The Prosident took action so rapldiy that he did not oven pause to notify the American delegation at the Ceneral Assembly prior to his announcement. At the time, the American delegation was presaing a plan for temporary trusteoship, having asked the Counc1l to suspend the implomentation of the partition plan. 
of great powers was demonstrated in the Indonesian ease, where again the lasting political solution was efrected by the influence of a great power.

\section{The United States Definition of "Threat to the Peace"}

In the Berlin question the American definition of what constituted a threat to the peace was summariged by Jesaup in aking that chapter VII of the Charter be invoked. According to Jessup, a "threat to the peace 1 s created when a state uses force or the threat of force to secure compliance wth 1 ts demonds ..." Phis definition maintained that "when the act 18 aggressive and threatens the use of force, but falls short of an armod attack, 1t constitutes an act of aggression or a threat to the peneo..." Jessup concluded that armed attack might be repelled by armed attack under the right of self dofense, Individually or collectively, under Art1010 51 of tho charter.

\section{1}

U.H.S.C. Off. Ree., 4th Ir., 398th Heeting, 11 Januar $1949,10.2, \mathrm{pp}, 2-10$. The United states denounced the retherlands government for 1ts non-cooperation with the Committee of Good offlces and for 1ts violation of the charter by the 11legal use of force in open deflance of an order of the Security Counc11. The United states delegation then concluded 1 ta position by announcing the admiration with which 1 ts government viewed the efforts of the Indonesian poople to gain their independence, and stated that the United states would continue to support them in an endeavor to work out a peaceful adjutment of the dispute.

2

U.H.8.C. Off. Rec., 3rd Yr., 363rd Meeting, 6 october 1948, 110. 115, pp. 1-27. 
The Position of the Onited States on the Implementation of a United Nations

Collective Securlty Pollex

and the Veto

At the San Frencisco Conference the United States delegation, confronted with strong resistance from many delegates to the exercise of a negative vote by permnent member which produced the requirement of unanimlty among the permanent members (the veto), had contended that the veto would be exerolsed seldom, If ever. It implied thet fallure to agree to the unanimity prineiple among the permenent members would be tantamount to defeating acceptence of the Charters and, furthermore, that the greet powers would use the veto for the interests of the world organization rather than for their own selfish interests.

The extreme position regarding the unanimity princ1ple--adhered to tenaclously by the United States at Sen Franolsco-was modified in the process of considering the Greek question. The United States had sponsored resolution establishing commission of investigation consisting of one 2 representet1ve of en member of the counc1l. The commisston had investigated the question on the spot from January to

United Netions Conference on International OrganizatIon Documents, Vo1. II, Commission III, Security counc1, (New York, 1945), $p, 493$. For the atrong objections to the veto principle as set forth see the reports of committee III/I, pp. 429-531 of Vol. 11. Hereafter referred to U.N. Conf. Intnt 1. Org.

U.N.S.C. Off. Rec., Ist Yr., 2nd Ser1es, 87th Meoting, 19 December 1946, 10. 28, pp. 700-01. 
1

Apr11 of 1947, then submitted a divided report. During July and August of 1947, five proposals had boen mado and rejected In an attempt to resolve the 19sue. The Unfted States had then proposed the establishment of a commission to 1mplement the recommendations of the investigation commission. When this proposal had boen refected, the United States then proposed that the Counoll determine that a throat to the poace existed under Chapter VII of the Charter. In anticipation of a rejection by reto of the second resolution by the Union of Soviet Socialiat Republica, the American view was strongly worded. The United States delegation contended that auch a veto in the council could not "preclude individual or colloctive action by states willing to act as long as they act in accordance with the general purposes and principles of the United Nations." ${ }^{2}$ Nevertheless, the second proposal was also rejected, and, after much debate, the UnIted States proposed that the matter be dropped from the security Counc1l agonda and sent to the General Assembly.

The negative vote by the U.S.S.R. In the Corfu Channel case had prevented the scceptance of the report of

1

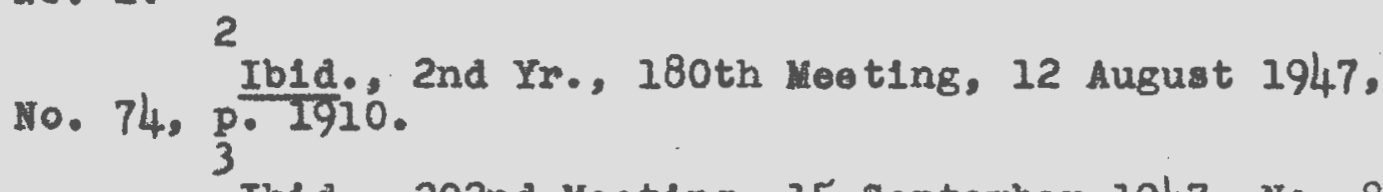
p. 2405 .

Ib1d., 202nd Meot1ng, 15 september 1947, No. 89, 
1

the Investigating subcomatteom-a report which clearly imputed Albanian responsiblilty for the laging of the mines 2

which hed damaged Britigh warahtpa.

The Greok question and the Corfu Channel case brought forth the problem anticipated by ny of those at San Franclscom-the obstruction of the Counc1l from performing 1 ts steted purpose by the use of the veto. The United States modified her san Prancisco position and oven went so far a to take the position that she would disregard the veto in order to carry out the purposes and prinolples of the charter.

$$
\frac{\text { American Polloy by } 1950 \text { on }}{\text { Chepters Vi VI and VII }}
$$

By February 1950, the United Stetes had clarif1ed her position in regard to chapters V, VI, and VII of the Charter. Gross' sumery before the counc1l that month olearly showed that the American policy of collective security through the Onited Nations meant that the Unt ted States Intended the Unfted Nations to play atrong part in the settlement of International alsputes. A regular procedure for handing disputes was developed in which the situetion was to be kept as much as possible within Chapter VI

U.N.S.C. Off. Ree., 2nd Yr., 122nd Meoting, 25 March 1947, 10. 29, pp. 608-09. 2 Io1d., 120th Meeting, 20 March 1947, No. 27, Supplement 10, Annex 22, pp. 77-109. 3 Ho. 9. $\mathrm{pp} \frac{\text { Ibld }}{12-18}$. 
(Pacific Settloment of Disputes) of the Charter. This was to bo accomplished by: the establishmont of commissions of investigation, the facilitation of negotiation, truce commisions, and other means which might ald the effectuation of a lasting political solution by the parties to a dispute-all under the aegis of the securlty counc1l.

If the measures advanced by the counell under Chaptor VI were deomed to be inadequate, Chapter VII should be invoked by declaring the existence of a "threat to the peace," a "breach of the peace," or "an act of aggression." The Counc1l should then make 1 ts recommendations, and the various nations should move to lmplement these recomendations, placing great rellance on the subsidiary organs established by the Counc1l.

If the council (In the performance of 1 ts "primary responsibility for the maintenance of international peace and securfty" as stated in chaptex V) were to be obstructed by negative vote of a permenent. member, such a misuse of the veto was not to "preclude individual or collective action by tates willing to aet as long as they act in accordance with the general purposes and principles of the United Nations." Thus, "strict" interpretation of the voting procodure in regard to permanent mombers under Chapter $V$ was to be avolded. Instead the Unfted States ravored a "loose construction." Sho advocated strongly the interpretation that the veto was to be used seldom if at all, and that 
action in conformity with the purposes and principles of the United Hations Charter could be taken even though veto had been used. In effect, the United States' position wat that a miause of the veto rendered the veto unenforceable. By the time the Korean problem came to the attention of the Security Council in 1950, Amerloan polley in regard to the veto had changed considerably from the views the olted states had expreased at San Franc1sco. Prom the extreme postion of inulatence upon the prinetple of unanimtty, the Inited States'position had been wollified to the point wher It advocated the disrogard of a toto (whon a sufficlent number of the security Counc1l delegations indicated that the w111 of the Coune11 might be obatrueted, and th cound might be rendered incapable of performing its responsibilities under the Charter). The United States had followed a consistent polley of atrongthening the authority of the United Hations as each case was considered. American poliey regarded the United Nations as an International authority ath greatly expended powers of Investigation and with the ablitty to advocate strong enforcement moasures if necessary to malntain international peace and security. The Korean problem provided the ocosion ror the United States to go so far as to adrocate tho use of tho Generel Assembly to support onforcoment mosures--even if this polley meant the reversal of the position held by the United States at San Pranciseo. 


\section{CHAPTER III}

THE BACKOROUND OF THE KOREAN PROBLEM, 1945-1950

\section{Korea's H1storical "Independence"}

Unt1l the Japanese-Korean troaty of 1876, Korea had been a dependent of China, exercising local autonowy, but paying tribute to china and boing rogarded as hor ward. Japan 1nterproted the treaty of 1876 as granting Korea in1 dependence in the western sense and proceoded to explo1t Koroa until conflict with China over their oompeting interests culminated in the Sino-Japanese war and the end of the "shu-pang" relationship between China and Korea." With the Ireaty of Shimonosek1 (1895) Korea became an Independent soverelgn state under Western international 1aw. Rivalry betwoen Japan and Russia led to the Russo-Japanese war, and in the Treaty of Portsmouth (1905) Russia, as the 10ser, acknowledged Japan's paramount interest in Korea. On November 17, 1905. Japan secured control of the forelgn relations of Korea by treaty, and Korea became protectorate of Japan with

M. Frederick Nelson, Korea and the Old Orders in Asia (Baton Rouge, La., 1946), pp. 131, 134-37. 2 Ibid., pp. 212-13. 3 4 Ib1d., p. 242.

W11liam L. Langer, An Encrelopedia of Morld History (Boston, 1948), p. 892 . 
1

American consent. The second world war brought far-reaching changes in Asia and, wi th them, the renewod question of Korea's "Independence."

Whon President Roosevelt, Prime Minister Churehill, and Generallssimo Chlang Kai-shok mot at Calro from November 22-26, 1943, they latd the foundation for the postwar polley in Asia which later met with serious difficulties In Korea (Russia was not represented at the Cairo Declaration. not boing at war with Japan the time). The decisions of the moting were olearly stated:

The Three Great Allies are fighting this war to restrain and punish the aggression of Japan. They covet no gain for themselves and have no thought of torritorial expansion. It is thoir purpose that Japan shall be strlppod of 211 the 1alands in the Paciflc which sho has selzed or occupled sinee the beginning of the First World war in 1914, and that all the territorles Japan has stolen from the Chlnose, such s Manchurla, Pormosa, and the Pescadorea, shall be restored to the Republic of China. Japan 111 also be expellod from 211 other territorles which she has taken by $\nabla 10$ lence and greed. The aforesald three great powers, mindful of the enslavement of the people of Korea, are determined that in due courge Korea shall become free and independent.2

\section{Allied Agreement 8,1945}

At Potsdam, July 26, 1945, the President of the

United States and the Primo Ministor of Great Britain signed the Potsdam Proclamation (coneurred in by despatch by the President of the National Government of China) confirming

M. Frederick Helson, Korea and the 01d Orders in

As1a, pp. 267-71. Japan annexed Koree bJ 1910.

2

Cairo Declaration, cited by harold R. Isaacs,

New Crole in Asia (Ha York, 1947), p. 29. 
the Calro Declaration: "(8) The torms of the Cairo Deolaration shall be carried out and Japanese soverelgnty shall be Ilmited to the islands of Honshu, Hokkaldo, Kyushu, Shikoku and such minor 1slands as we determino." ${ }^{2}$

On August 6, 1945, an atomic bomb was droppod on Hiroshima. On August 8, a bomb was dropped on Nagasak1, and tho Soviet Unfon declared war on Japan and Invaded Manchuria. On August 10, the Japanese govemment announced readiness to surrender. In her declaration of war agalnst Japan, the Soviet Union associated herself with the plodgo contained in the Calro Declaration and confirmed at Potsdam, that Korean Independence would be restored in "due course." As a result of a military decision to effoct the aurrender of Japanese forces in Korea, Japansse troops north of the thirty-aighth parallel wore to surrender to soviet forces, and those south of the thirty-elghth parallel were to surrender to United States forces. After thls decision had been put into effect, in September, 1945, the thirty-1ghth parallel was interpreted by the Soviot ocoupation authorities to be a permanent delineation between two milltary zones. The United States commander attempted to negotiate arrangements whlch would allow passage botween the

\footnotetext{
Potsdan Proclamation Dofinling Terms for Japan's Surrender, cited by Isaacs, Ner cyele in Asia, pp. 5-6. 2 3 Ib1a.s. p. 3 . Ib1d., p. 88.
} 
two section of the countip, but tho soviot ocoupation authorlties regarded the delineation as military one, and the questlon was taken up on a governmental level.

In December, 1945, the Fore1gn Ministers of the Dalted States, the United Kingdom, and the Soviot Union, meoting in Moscow, arrived at agroement concerning the future stetus of Korea. This Moscor agreoment reeelved the adhorence of the Chinese Government also. It provided ror (I) the "oreation of conditions for developing the country on demoeratio principles"; (2) the eatablichmont of a Jolnt Comalsalon, conslating of repreaentatives of the United state commend in southern Iorea and representative of the Sovlot command of northorn Koro, to assiat in the formation of a provtalenal Korean governmont (3) the submission of proposals of the Joint Commisston Honcerming a four-power truateeship of Korea for perlod up to five Jeara" to the folw powers and (4) a conference within two weeks of popror sentatives of the Onited states and soviet comands in Korod for the purpose of effeoting permunent ooordination in admin1strative-economic natters botween nopthern and southori 2 Eerea.

Desdlock of the Joint Cominlssion

The Jolnt Commission mot on Varch 20, 1946; but soon

0. S. Department of state, Korea 1945-1948, Publ1cation 3305. (Washington, 1948), p. 3.

Cosumique of the Moscow Conference of the Three

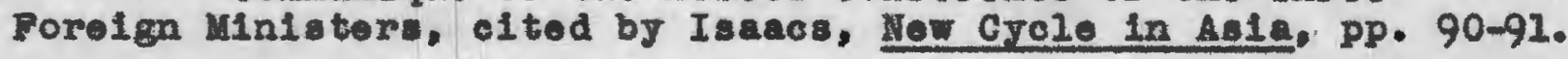


became stalomated through inablilty to agree on the definition of the word "domocratie" as 1t pertalnod to reprosentetives of tho partios and soclal organisations montioned in the Loscow Agreement, and the Commisation adjourned alne de on May 8,1946 . In a lottor delivered to poralgn Miniuter V. W. Molotov during the Forelge Miniaters 'Conferenee in Moscow In Apr11. 2947, Oeneral Goorge Marchall (United State. SecretsieJ of state) brought tho matter to the attention of the Sovlet Forelgn Minister in requesting that the Jolnt Comianion reconvene.

\section{Molotov replied a for day later w1th a proposal} that the Jolnt U.S.S.R.-U.S.A. Comalistion regume 1 ts work on Mey 20, 1947. In order to Implement the Moscor Agreoment portalning to Korea. Molotor also proposed that duplng July and August of 1947 the comalasi on should "aubult to the two governmonts for conslderation the results of its work in - laborating recomendations in reapest to the eatabli whent of a provialonal Korean dowoeratie government." ${ }^{2}$

The Jolnt Combission reconvened on ray 21,1947 , and soon became stalomated again. The bnited Statos and Soviet delegetions were not even able to agree on jolnt roport on the atatus of tho dellberations in the Jolnt combision.

\footnotetext{
1

Marshall Lettex on Korea, eltod by Isaacs, Nov Crele in Aale, Pp. 94-96. pp. $96-99$.

Molotor'a Reply, elted by Iseaes, Her Cyelo in Asie,
} 
The United Stated then proposed to the Soviet Union, on August 26, 1947, thet four power moetings bo held to oonsider how the Mosoow Agreement could be speedily carried out. On September 4, 1947, the Sovlet Uni on rejected the proposal-on the grounds that such a conference would be outside the scope of the Hoscov Agreement. The Untted States, feeling that further nogotiations with. the soviet Uni on were futile and would only delay the urgent claims of the Korean people to Independence, brought the whole question of Korean independence before the General Assembly on september 17, 1947 .

Kores Before the Ceneral Assembly

The question of "the Independence of Kores" came before the secand segular session of the General Assembiy, a session that was noted for the consplouous acrimony and bed feeling between the Unlted States and the Sorlet Union. When the Unlted States representative introduced the problem for consideretion by the First Comittee, he blamed the U.S.S.R. for the fallure of the Jolnt Commlssion because it had refused to grent consultations to polltical parties and oolal organizations opposed to trusteeshlp. He declared that his country (United States) was enger to witharew her

\footnotetext{
J. S. Department of State, Korea 1945-1948, pp. 5-6. 2

Eugene P. Chase, The United Nat1 ons in Action (New York, 1950), pp. 113-15.
} 
troops, but auch a wthdramal would have to follow the formation of a ingle government roprosenting the Korean people. He proposed the etablishment of anited Ilation Romporary Comidalon to observe electiona with the purpose of establiohing a National Assombly. Fals Assombly would then form a netional government for all korea and take over the runetlons of the commanders of the decupation forces in Korea.

The J.S.S.R. cherged that the Unitod States had violated hor obligations under the Moseow Agreoment in regard to the selection of the polltical perties and soelel organications ontitled to be heard. It ras fur ther chargod that the United States had rejected the U.8.8.R. proposal on the -stablishmont of a Koreen Constituent Assembly which would consist of representatives of the politieal parties and -ocial organizations with whleh Korea wight form provialonal government. The soriets stated that the United states had refused to accept their proposel advoenting almultanoous withdrawal of the U.S.S.R. and American troops from Kores early In 1948, and, therefore, the Dnited statos was reeponetble for the breakdown in the Jolnt comisalon. The U.8.8.R. maintained unsuccessfulis that the Korean question. In the

\section{1}

United Hations Seezetariat, Research Section, Baokground Papers, Mo. 62,28 yny 1950, p. 4. Eoreafter reforred to as U. M. Secrotariat. 
samo eategery as other question connected with peace treat1es, should be dooldod by the two powers concemed and did not 110 within the Jurlsdietion of the United Iations. The Soviot governmont held that a free govermment could not be atablishod until after the oomplote withdrawel of forelgn troops; tharefore, the Gonoral Assombly should censult with representatives of the Korean people befere inaking decision on the matter. The O.S.S.R. Introduced proposal to invito representatives of the Korean poople from Southern and Northem Korea to take part in the discuselon of the queotion. The Unitod states maintalned that such consultation should be hold in Korea in order that onitod Hations Comntsalon might be able to ascortain who the elected representatives of Rorea might be. The majority of the Political Committee favored the Amerloan view; as a result; the 0isisin: doclared that if a Unitod Hations Tomporary Commiseion wore to be set up $\mathbf{1}$ thout tho partalestion of the Eorean poople In the discusalons of the Genorel Hatembly, the V.S.S.R. would be uneble to take part in the commisaton.

1

U. Searetariat, Howeavet Section, Beokground Papers, Ho. 62, 18 yey 1950, p. 5 . 2 Ibid., p. 6

3

Onited Mations General Assembly Orflelal Records. 2nd seselon, 1947, Summary Record of lloetinge, 16 september19 Hovomber, Plrst Complttee, p. 281. Horeafter referred to as D.H.G.A. Orf. Hoe. 
United Nations Temporary Commission on Koree

Hevertheless, on November 14. 1947, the Conoral

Assombly proceeded to form onltod rations Temporary conilleaion on rorea. The task of the commision was to facilitate the ottablishment of national government of Kores by mont of nation-wide elections and to provide for the withataral.

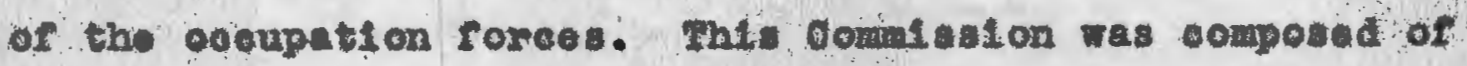
Aubtralla, Canada, Ohlne, II salvador. Prance, India, styto Philipplnos, and the Utratnian soviet soolallat Republie. It wa uthor1sed to trevel, observe, and consult throughout Korea. The Ukrainian S. S. R. Werubed to particlpate trithe vork of the Commisst on on grounds elmilar to those prosontrid by the T.S.A.R.

The Temporary Comalasion endearored to carry out 1 ts tauk, but wes unable to make contact with military authoritioa In North Korea:- The J.S.S.R.'s permenent ropresentatives at the United Nations beadquartere made pererenees to the mistt1ve" attitude of tholr governwent toward the establi chmont of the Temporary Countssion In Korea. The Commiselon thon decided to conoult with the Interin committeo in order to obtain 1 ts riew on a method of procodure.

The Interin Comittee

The Interim Comitteo had been ostablished by the

0. H. Secretariat, Researoh section, Baokground

Papors, No. 62, 18 uay 1950, pp. 6-7. 2 Ibid., pp. 7-8. 
Ceneral Assembly in Horember of 1947 to function until the next regular session of the Assombly. Among 1 ts powers vere those authorizing the remporary Commission on Korea to consult the Interim Committee with respect to the applicetion of the Assembly's resolution establishing the Temporary Commission. (The 0.3.3.R. had atrongly objooted to the estab11shment of the Interim Comittee and had rofused to participate In 1ts work, on the grounds that it was a violation of tho Cherter and was an unconstitutional mothod of aroiding the unenimity rule of the Securlty Couneli--a deviee which ultimately would usurp the powers and prerogatives of the Security Council 1tself.) 1

The Temporary Comisaton informed the Interim Committee that under the General Assembly resolution it was to be concerned with the whole of Korea and not Just one part of 1t. Under the clrcumstances, most of the mombers of the Temporary Commission felt that the formation of a soparate government in South Korea could not be a "national governmont", nor would it facilitate the withdrawal of the occupyIng forces. The Australlan representative belleved that an election in only one pert of Korea would be contrary to the

U.H.G.A. Off. Ree., 2nd Seation, Summary Record of Meetings, 16 September-19 Horember 1947, First comalt tee, pp. 329-35. The representatives of the Bjelorusalen soviot Soclallst Ropubilc, Crechoslovakia, Poland, the Ukrainian S.S.R. and Yugoslavie sided with the Russian argument, and also refused to partioipate in the work of the Interin committee. 
Goneral Assembly resolution, and that the setting up of a government in the South would give rise to the establishent of government in the Morth--which would place the Inlted Vations in a dificult position. The Interim Comitted, nevertheloss, declded on February 26, 1948, that the Temporary Commission should Implement the Generel Assembly'a resolution in such parts "as are accessible to the Commiseson. ${ }^{1}$

The Formation of Tro Rival Governments in Korea

The Temporary Combialon could not galn accosd to North Korea, but proceeded to supervise eloctions on vir 10. 1948, in gouth Korea. The oloction in South Korea resulted in the majority of seats in the Hational Assembly going to the National Assoclation for the Rapld Realization of Korean Independence (Ied by Syngman Rhoe). The Commission observed that "only fightist parties and groups had officially supported the eloctions." It also observed that, alnce the - lectlons were restricted to South Korea, they "woro opposed by some political partios and kindred organisations in that area. $n^{2}$

In the meantime, according to the Comalssion's bot Infornation (1t had no direct contact with Vorth Korea) a

U. H. Secretariat, Hosearch Section, Backgroung Papera, No. 62, 18 May 1950, pp, 8-9. 2

U. N. Secretariat, Research Section, Background Papors, Ho. 62, 18 uay 1950, pp. 9-11. 
xival government had been formed under Goneral IIn II sung. This government of the forth elalwed that 1,080 representet1ves from South Korea had met in Haejn in Horth Korea and had locted 360 Assemblymon. The 360 Assemblywen lectod by the delegated from the South combined with the 212 Iot the Korean Assemblymen elesmed to constltute the supreme People is Asembly, and, on September 9, 1948, they ostablished the Government of the Pooplo's Republlo of Korea. In Oetobir, the U.8.3.N. recognized the northern government, the Democratle Pooplo's Republic of Korea, and later 1t was recognised by some ton other states. In Fobruary, 1949, It applled for membership in the United Hations, but was wht jocted.

The Temporary Comalsaton, In Its report to the Ceneral Assembly, called attention to the fact that a eoparate government had been establlshed in the north vi thout consulting that commission and recommonded that the govisum ment in the south be recognized by the Assembly. It urged unfiestion of the country as a nocessary prerequisite to the wthdrawal of the occupying forcos if wn internocinb war were to be avolded.

1

U. I. Secretarlat, Research Seotion, Background Paport, Ho. 62, $18 \mathrm{Mag}$ 1950, pp. 11-13. 2

Ib1d.. p. 13. 
The General Assembly established new Comission (the alx states that had refused to partielpate in the work of the Interim comnitteo again refused to vote, reltorating their objections) and announced the establishment of 1arful government (the government of the Republlo of torea) Whaving erfootive sontrol and furideletion over that part of Korea where the Temporary Commisalon was able to observe and conault and in which the great majerity of the people of all Korea reside; that this Governmont $1 \mathrm{~s}$ based on oleetions whioh were a valld expression of the froe will of the electorate of that part of Korea and which were observed bJ the Touporary Commission; and that this is the only such Govornmoṇt in Koron." ${ }^{1}$

The Government of the Republic of Korea was granted rull rocognition by the United States in January, 1949. It has also been recognized by the National Government of China, Pranoe, the Unitod Kingdom, Phlilppines, and othor atates. Formal application for momborship in tho Onltod fations was made by the Republic of Korea in January, 1949, but was rojocted bJ a negative rote of the Soviet OnIon, although it

$$
\text { U.A.G.A. Orf. Rec., Plonary leetinga, 3rat Session, }
$$
Part 1, Annexes to the Sumpary Records of Leotlugs, 1948 , DoC $1 / 788 / \mathrm{pp} .549-51$, Par. 2 of the hesolution edopted by tho Ceneral Assembly at the 187 th Flonary moeting 12 Docomber 1948. Par. 9 of the same resolution recommended that Milomber states and other nations, in ostablishing their relation. with the Government of Korea, take into consideration the faets set out in Par. 2 of the present resolution." 
met all the requirements for aeceptance by that body with 1

nine rotes in 1 ts 'revor.

\section{The Withdrawal of Occupation Porces}

The Inited Nations Comisaion observed and verifled the witharawal of American ocoupation forces, which was completed on June 29, 1949. M11tary material was not withdrawn but was transferred to the Korean security forces. An Ameriean Milltary Advisory Group of 500 men remalned in order to give advice to the Korean Milltary Academy.

The Commission olgnifled its roadiness to offor its services, as directed by the General Assembly resolution of December 12, 1948, to observe the wthdrawal of 0.S.S.R. occupstion forces. Yo reply was received to its request from the Soviet Government, but cocording to Tass, tho Soviet Hews Agency, Sorlet evacuation was oompleted on December $25,1948 .{ }^{3}$

The Comnission's Conclusions of JulJ, 1949

By July, 1949, the United Hations Comasision was ablo to sumarize the results of 1 ts expexienes in Korea. It stated that the covernment of the Ropublic of Korea had maintalnod a negative attitude with respect to the Comalisalon's

1

ט. H. Secretariat, Reseurch Section, Background Papors, Ho. 62, 18 May 1950, p. 15 .

2.

Ibld., . . 19.

Ibld., p. 20. On September 18, 1948, the Forelgn Ministry of the soviet Union had notifled the United states Government that the ovacuation of Sovlet troops from Iorth Kores wevild be completed at the ond of December, 2948. 
ondearors to establish contact wth the Horth. The Comenision folt that the Republis was still politically divided Internally by breach stemaing from the differences of views over the elections of $\operatorname{Mag} 10,1948$. The Comatsation folt that the government had made no attempt to hoal the breach and that, as a reault of tho activitles of the North, 1t hed adoptod a somewhat brutal attitude in 1 to condret, which had engendered suapletor of those who were independent or eritical in pirit. The comisalon maintained that the Korean problem was besicelly one phese of the world-wide antagonism between the Un1ted States and the U.S.S.R., and that no subatantiel progress toward the echlevement or walty In Korea could be made without an underatanding on the problen by those two powers.

\section{The Renewal of the Commission, October 21,1949}

When tho Commisaton applied to the Ad Hoe Polltion Comaltteo for continuation of the complasion wh onlarged powers, a Philippine proposal was adopted to invito the delegation of the Republic of Korea to participate, without vote, in the discussions of the committee. Representatives of Horth Korea vere excluded inee they Fefused to resognise or cooperate with the United Nations Comalssion on Korea. The U.S.S.R. maintainod that the United states had created a

0. H. Secrotariat, Research section, Beckground Papers, No. 62, 18 Nay 1950, pp. 20-22. 
$-30=$

puppet government in south Korea and pressed for the 1 inmediate termination of the Commission. The United States urged continuation of the Comisalon, warning of the growIng danger of a "cruel e1v11 war." on october 21, 1949, the General Assembly approved the renewal of the comalsalon with - lIghtly expanded powers and th some alteration of purpose. The fret task of the renewed commission was to "observe and report any developments which might lead to or otherwise involvo military conflict in Korea." ${ }^{2}$

1

T. N. Secretariat, Research Section, Background Papers, No. 62, 18 May 1950, pp. 22-29. 


\section{CHAPRER IV}

ARIID CONFLTCT IN KOREA AND THE APPEAS FOR

COLLECTIVE ACTION THE RESOLUTIONS OP

JUNE 25 AN JUIE 27,1950

The Composition of the Securt ty counc11

From danuary unt 12 Ausust, 1950

At the firat moeting of the securlty coune12 on

Januery 10, 1050, the U.8,8. B. brought to the attention of the Couno11 requests fra the Central People's Govemmont of the People's Repub11. of China. Those requests stated that tho goverment of the Pooplots Republis of Chin hold the presence of "the delegates of the chinese Kuomintens reactond romnant alque (Rationalist Chinose delegates) In the seourlty Counc11 to be 111 egal, and aked for the expulation of those delegates. The U.s.s.R. then submitted

- rovolution to tho councli alling for the excluaton of "the representative of the Kuontntang exoup." The U.S.S.R. took the post tion that the Kucinintang delegato represented nelther ching nor the chineae people and gro notice that 1 f the counoll falled to take ppropriate atton, tho U.S.S.R. would not partidpate in the work of the counc1 as long as that delegate had not been excluded.

U.N.S.C. off.Ree*. Bth Ir.*45eth Hoeting,

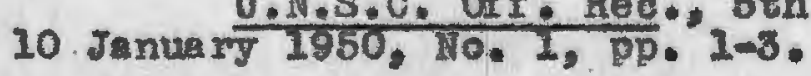


The Yugoslav delegate supported the soviet resolution, polnting to the fact that five governments represented. on the Counell recognized the now governmont of china and five governmente recognized the old one. He tated that the inoreasing number of recogaltions was due to the fact that it had become obvious that the soverelgn w112 of the Chinese people had been expressed in the establishment of the Covern1 mont of Mno Tse-tung. Devertheless, the soviet resolution wes refeoted, and the representative of the U.S.S.R. Ioft the Counc1l chamber with the atatement that the U.S.S.R. would"not reoognize as legal any docialon of the security Coundil adopted wth the participation of the ruomintang group," and would "not be gulded by any ach decisions." "tho soviet delegate did not roturn to the coune1I unt11 August 1, 1950.

\section{The June 25 Resolution}

On June 25, 1950, the security Counc1l convened at the request of the United States to consider a reported

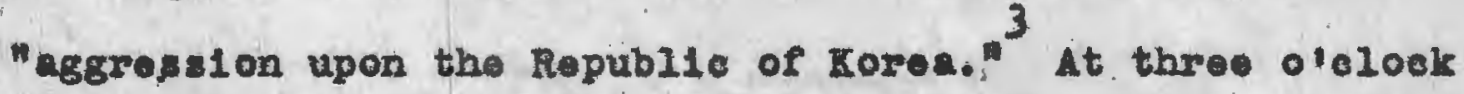
of that nowning. Smost Cross," the Amoriean representative, had read a measege to the Presldent of the security Counc1l

\footnotetext{
O.H.S.C. Orf. Hec., 5th Ir:, 460th Hoeting, 12 Januery 1950, Ho. 2, pp. 2-4. 2 pp. $9-10$. Ib1d., 461st Hoeting, 13 January 1950, Mo. 3. Ibld.. 473rd MeetIng, 25 Juno 1950, No. 15, p. 1.
} 
which stated:

The United States Ambassador to the Republic of Kores has Informed the Department of State thet North Korean forces Invaded the territory of the Republic of Korea at several polnti in the early morning hours of June 25 (Korean time).

Pyongyang Radio under the control of the North Koreen regime, it is reported, has broedeast a declaration of war agalnst the Republio of Kore effective 9 P.M., E.D.T., June 24.

Tpon the urgent request of my Government, I ask you to call an Immediate meeting of the security Counc11 of the United Mations.2

At the opening of the meeting of the security

Counc1 a cablegram from the Unt ted Nations Commission on

Korea was introduced, whl oh read:

Government of Repub11 o of Korea stetes that about $04.00 \mathrm{hrs}$. 25 June attacks were launched in strength by North Korean forces all along the thirty-elghth paralle1... Pyongyang rudio liegation at 13.35 hre. of south Korean 1nvasion cross perallel during night deolared entirely false by Preeident and Forelga Minlater in courae of conference with Combission members and Prinolpal Secretary. MIlegations also stated People' Army instructed repulse invading forees by decisive counter attek and placed respons1bility for consequences on South Korea . . .

Cosemis a on wished to araw ettention of secretary. cenerel to serlous situation developing whioh 18 assuning character of full-soale war and ma ondanger 2 the maintenance of intermational peace and security....

The United States representative then submitted a resolution which called upon the North Korean authorlties to

1

U.N.S.C. off. Ree., 5th Ir., 473rd leeting.

25 June 1950, 10. I5, p. I, n. 2 Iold., p. 2, n. The cablegram wa dated June 25, 
cease hostilities and to withdraw tholr armed forces to the thixty-elghth parallel. The regolution also called upon "all Member to render every assistance to the United Nation in the exocution of this resolution and to refraln from giving asalatance to the North Korean authorit1es." The cautlous reaponse of the United IIngdom to the American resolution is noteworthy. Sir Gladwy Jebb held to the v10w that certain amount of restraint was necessary and that "the security Counc1l hould not at this moment take action which might bo boyond the bounds of the evidence which has been placed at 1to disposal by its own Commlssion In Korea." The Yugoslav delegate proposed that the counc1l enlarge the bounds of ovidence by granting an opportunity for a ropresentat1ve of Horth Korea to present his case. Unt1l that transplred, ho ald, final judgment should be withhold. After calling attention to the fact that the Counell had hoard the reprosontative of South Rorea, Mr. Ninele introduced a resolution that would have granted a simllar privilege to a representative of North Korea.

The American resolution was adoptod by nino rotes in favor, Iugoslavia abstalning, and Russia absent.

U.N.S.C. Off. Ree., 5th Xr., 473 rd Moeting, 25 June, 1950, No. 15, pp. 4-15. 
The Iugosiar resolution was refocted, six rotes ageinst, throe abstentions, and one absent. 1

Recommendations of the United Hations Commission on Korea:

On June 27, 1950, the Soourity Coune11 met to Fenew 1ts considaration on tho Momplatnt of Aggression upon the Republic of Korea." Four eablograne had been recelved from the oomisaton in ropig to a request which had been included In the security Council's resolution of June 25.

The first cablegran statod that Iorth Korean advences had created a dangerous stuation with posalbilitios of rapid doterioration, and, in the light of past experienoe, the Commission was convineed that Horth Korea would nel ther heed the Councli's resolution nor sccept its good offlees. It auggested that the Coune1I el ther Invite both parties to agreo on a noutral modiator to nogotiete pace, or that the Coune11 request Nember Governments to undertake immediate mediation.

The last cablogram stated that the Coamlsalon had mot to consider the latest reports on hostilities and the roults

\section{U.H.S.C. Orf. Ree., 5th Yr., 473rd Heoting,} 25 June, 1950, 10. 15, pp. 16-18. The prodedure of the Socurity Councll callod for a voto on the American resolution first. Inmediately after the presentation of the Yugoslav resolution, the delogate of Norway, $\mathbf{M r}$. Sunde, tated that his sountry would support the American resolution. The Counc1I then moved to rote on the Amerioan reselutior immediately. There was no opportunity given to diseuss the Iugosiav rosolution which was put to a vote after the councli had adopted the one proposed by the United states. 
of "direct observation along the parallel by oxcor military observar over period ending forty-eight hours before hostilitios began." Tho Commisulon's view on the basls of that ovidence was that the Horthern Reglwo was carrylngi out - "rioll-plannod, concertod and full-scalo invasion of South Xorea"; that the "South Korean forces were doployed on a wholiy defonsive basis"; and thet tho south Korean forces "were taken completely by surprise, as they had no reason to believe from Intelligance cources that invasion was lminont. ${ }^{1}$

\section{The Amertcan Position of June 27}

Warren Austin, speaking for tho United States before the Socurity Counc1l, callod attention to the roport of the United Nations Commission for Koren whlch confirmed that the armed invasion of the Republie of Korea was continuing. He noted that the seourity Council's call for a cessation of host1lities had been broadcast to the forth Korean author1t1es, but that they had completely disregarded 1t. The con-

$$
\text { U.A.S.C. Orf. Roc., 5th Ir., } 474 \text { th Moeting, }
$$

27 Jun $1950,10.16, p \cdot 2$. The last report of the com-

mission clted here ( $8 / 1507)$ deserves some speclal attontion. No dato was given in tho Security councll Records to indicato the time it was sent, but, aceording to other recorda, the date was June 26 (Rorean date). (U.N.G.A. Off. Rec.. 5th Session, Report of the Unlted Hations Cormission on Koree 19 Docember 1949 to 4 septamber 1950 , Supp. 16, New York 1950, p. 3.) Howerer, the " on the spot obeorvations by the military observers of the 0 . N. Commission terminated 48 hours prior to the commenosment of hostilities. Therefore, in this roport the information concerning attivities at tho time of commencemont of hostilities was drawn by the cormission frow covernment of horea sources. 
EInued armod attack upon the Republ10 of Korea was then, according to Austin, an attack upon the United Nations iteole.

Since the most important provialons of the Oharter were those outlawing aggressive war, and since these were procisely the provision which the North Korean authorities had violated, the plain duty of the security. Oouncil was to invoike tringent sanotions to restoro international pesce. Since the Republic of Forea had appealed to the Initod Iations for protection, Austin was happy and proud to report that the Onitod States was proparod, as a lojal mombor of the United Natione, to furniah assistence to the Republ10 of Korea. Accordingly, he submitted a dref resolution for the councll to consider as the next top to restore world peace. The resolution called attention to the appeal of the mopublic of Korea and rocommonded "that the Members of the Jaitod Nations furnish ouch assistance to the Repubilo of Kores as may be necessary to repeI the armed atteck and to restore international peace and security in the area." After submitting the resolution, Austin road a statement which the Prosident of the Onited States had made that dey (June 27th). In his statemont the President took the view that the attack upon Korea had made it Mplaln bejond all doubt" that Communiam had "passed bejond the use of subversion

1950, Ho. U.N.S.C. Off. Rec., 5th Xr., 474th Hoet1ng, 27 June, 
to conquer Independent nations," and would now "use armed Invasion and war." He made it clear, also, that the United States did not regard the attack on South Korea as simply a North Korean enterprise, nor the Americen Interest in Korea as detached from the Amerioan interost in China. Thus, ho deelared that since the Communists had defled the order which the Security Council of the Inited llations had 1ssued to proorve International peace and security, "the occupation of Formosa by Communist forces would be a drect threat to the security of the Pacific area and to the United states forces performing thoir lawful and nocosaary functions in that area." Thorefore, he had ordered "the Sovonth Fleet to prevent any atteck on Formose" and "the Chinese Covernmont on Pormose to cease all afr and sea operations against the mainland." Tho Seventh Fleet was to soe that hls orders oneorning Formese were carried out, and the determination of the future atatus of Formosa "must arait the rostoration of socurity in the Piclf1e, a pece settlement with Japan, or conalderation by the United Nations."

As supporting measures for this Pacific security action, President Truman revoaled that ho had dirocted that "Onited states forces in the Philippines bo strongthened and that military assistance to the Philippine Government be accelerated." He had also dirocted that "acceleration of milltary assistance to the forees of France and the associated states of Indo-China" be provided, together wth "the dispatch 
of anlitary mission to provide alove working relation with those forces. ${ }^{1}$

\section{The Position of Yugoslavia}

After Austin had offered the Amertcan draft resolution, the Tugoslav delogate reiterated his request for program of meditation. Ho stated the the war in Iorea was dreot consequence of the genexim 1 tension in the post-me world, which stenmed from the practice, "wldoly applied after the Second Worla War, of dividing oertaln goographleal areas Into epheres of Influence or interest." He Likenod this polioy to that to whitoh his own and other Balkan countries ha been subjected.

The Yugosiar delegato ouled attention to the fact that the Unt ted Nati ons Comalsal on on Korea had recommended the edoptlon of procedure of mediation In 1 ts cablo of June 26, 1950. In order to fadiltate this process, he proposed once more that the cound1 Invite the goverwaent of the Peoplo's Republic of Korea (Horth Korea) to end a representative to the headquarters of the Unfted rations Imediately-orth full powers to partielpete in the procedure of mediltion.

\footnotetext{
U.X.S.C. Off. Rec., 5th Ir., 474th Nooting, 27 Jane 1950. 20,16, Pp. $4-5$. Io1d. pp. $5-7$.
} 


\section{Other Att1tudes Expressod in the Secur1ty Couno il}

The moderate character of the Iugeslar proposal soomod to ombrace a view which was similar to that which the socurity counc1l had taken on provlous ocoastons in handling international disputes culminating in areed coneliet. It soon became apparent, however, that the atmosphere in the Counoll was to become one of condemnation of the Forth Korean authoritios. Previous procedure seemed to be forgotton in on offort to punish a group wich had flouted the authority of the Onfted Nations.

The next spokesmen after the Yugoslav delegate was the ropresentative from the Republlo of Korea (South Korea). He made a fervent appeal through the counc1l to all members of the United Nations to partiolpate net1vely in expeling "the marauding forces" wich had Invaded his eountry. Tho delegations of Prance and the United HIngerem then spoke in faror of the United States resolution. They were followed by the Chinese Nationalist delegation, which apoke out strongly against policy of modiation. The Ohinese Nationelist roprosentative stated that an offer of medition under the elfoumstances would only serve to condone an at of aggresalon. The event in Korea, he stated, had been ostablishod by the Commission as a clear case of unprovoled aggeesion, and the Invader had defled the authority of tho Soourity council. As for Fornosa, it was looked upon by the Ohinese people he sald In the same light as the other provinees of china, He 
expressed his gratitude, therefore, for "the declaton of the Enited States Government to use Its fleet to prevent an attack on Formose." The Chinese people, ho atated, "expeot theis Covernment to ut1118e the human and terlal resources of Formose to recover the termtorial integrity and the pol1tion Independence and rreedom of china." Cuba, Howrig. and Eouador added thelr support to tho Int ted Stetes resolution.

The meeting was then suspended for fite hours in order that the delegates of Igypt and India might recelve instructione from their governments. The Instructions were not recelved, however, and when the Un1ted stetes resolution was put to a vote it was adopted seren to one (Yugosiavia gainst). Tro did not rote (Egrpt and India), and one member was absent (J.S.S.R.). The Iugoulev amendment was rejected with seven roter gainat 1 t.

\section{The Positions of Bgrpt and. Indin}

By June 30,1850 , the delegates of Estpt and India ha recelved instructions from their governments and were able to conver the rlews of their governmente to the counall. Egyt steted that ahe would wate abatalned from roting on the resolution adopted by the cound1 on June 27 , had she

1950, $10, \frac{\text { U.N.S.C. Off. Rec., 5th Yr., 474th Mooting, } 27 \text { Jume }}{16, \text { pp. To11. }}$
Ib1d., pp. 11-17.


been able to pertidipate in the voting. The reasons given for Egypt's position were: first, that the conflict under consideration as a new phase in the series of alvergenoes between the westem and eastern blocs," a1vergences which themselves threatened world peace and security; and, secondiy. that there had been "sereral oeses of aggression against pooples and violations of the soverelgnty and untty of the territories of state Members of the Unt ted rions." on previous occeslons, Egypt held, when such ggressions and violations had been submitted to the United Nations, the latter bad not taken any action to put an end to them as it had done now in the arse of Korea.

The representative of India stated that the Indian Cablnet had found it necessary to spend two days considering the resolution, since India so near the scene of contict and would have to give most serlous consideretion to the implicationg and possible consequences of implementing the resolution. After this deliberation the Indien government had decided to "aceopt" the resolution, with the qualification that thls did not mean any ohnge in India!s forelgn polloy. India wa opposed to any attempt to settlo Internetional d1sputes by resort to foree, and felt thet "the haling of aggression and the quick restoration of peeceful conditions" were "essent1al preludes to a satisectory settlement." The

\footnotetext{
1950, No. U.N.S.C. Off. Ree., 5th Yr., 475th Meeting, 30 June
} 
govornment of India hoped that "oven at this stage" It might be possible to "put an end to tho righting and to settle the dispute by mediation, ${ }^{2}$

\section{The Position of the U.S.S.R. and other Communist Countries}

Since the Soviet Union was absont from the security Council motings during this perlod, hor views were sought through diplomatic channels. On June 27, 1950, the American Rmbassy at Moscow communicated with the soviet Poreign Ministor.

The reply Prom Deputy Forelgn winister Andrel Oromyiko stated that the Soviet dovernmont had ascertalned that "tho - vonts taking place in Korea were provolod by an attack by forces of the South Korean authoritles on border regions of Iorth Korea"; therefore, the responeibility for those events rested upon the South Korean authorities and those who becked thom. Socondly, sald Gromgke, "the Soviot Governmont withdrew Its troepe from Iorea earlier than the Goveramont of the United states and theroby confirmod 1ts traditional prinelplo of non-interforence in the internal affairs of other states." The Soviot governmont, added Gromjko, would continue to adhere to "the prinolple of the Impermiasibillty of Interforence by foreign powers in the internel affalrs of Kores." Thirdly, the sovlot Government was quite viling to take part

U.N.S.C. Orf. Roc., 5th Yr., 475th roeting, 30 June, $1950,110.17, \mathrm{pp} .2-3$. 
In the deliberations of the Security Counc1l, but was belng provented from dolng so because of the position teken by the government of the Onfted States, which precluded the admission of China (Communist China) to the Councli as a perment nember. The exclusion of comunist china from the Councli, according to the soviet Union, made it 1mpossible for the security Councll to meke declsions heving legel force.

Other Communist countries (except Yugoslavia) took a position almilar to that of the Soviet Union in denouncing the Securtty Counc1 1 resolutions of June 25 and June 27 at 11lega 1. The Minister of Fore1gn Affairs of the Korean Poopleis Democratic Republic (North Korea) sent a cablegram, dated June 29, 1950, to the UnIted Nat1ons, stating that his govermment did "not recognize the discussion and decisions of the security Council on the Korean question as lawful.

\section{American Pollcy on the Use of Armed Force to Restore Peaco in Korea}

At the meeting of the Securlty Counc1l on June 30 , 1950, the American delegation gave a sumery of the steps being taken by the United States to enforce the Securtity Councli decision. Thet morning, sald the American representative,

U.S. Department of State Bulletin, U.S.S.R. Responds to Requests for Mediet1 on, Vol. XXIII, No. 575, JuIy 10, 1950, relesed to the press June 29. 2 1950, No. D.M.S.C. Off. Rec., 5th Yr., 474th Meeting, 30 June 
the President of the Unlted States had met with Congressione 1 leaders, the secretery of Defense, the secretery of State, and the Jolnt Chtefs of staff, and had revlewed the situation in Korea. In keoping with the request of the Un1ted Netions Security Counc11, the President had announced thet he hed athorized the United States Alr Force to conduct missions on specific military tergets in North Koree wherever militarily necessary. He had also ordered a naval blockede of the entire Korean cosst. Furthermore, he had authorized General hicArthur to use certain supporting ground unts. Accompenylng this summery, wes a reference by Austin to a statement by the secretary of State on the previous day (June 29):

The President has enunciated the pollcy of this Government to do 1 ts utmost to uphold the senctity of the Charter of the United Nations and the rule of law among nations. We are, therefore, in conformity with the resolutions of the Security Councll of 25 June and 27 June, glving a1r and sea support to the troops of the Korean Government. Thls action, pursuant to the Security Counc1l resolutions, is solely for the purpose of restoring the Republic of Korea to 1ts status prior to the invasion from the North and of re-establishing the poece broken by that agression. The action of this Government in Korea is taken in support of the authority of the United Nations. It is taken fo restore posce and security in the Pacific area.

U.N.S.C. Off. Rec.. 5th Ir., 475th Meeting, 30June 1950, No. IT, p. 10. It Is interesting to note the implied IImitation placed on the commitment of American forces: "This action. 18 solely for the purpose of restoring the Republio of Kores to 1ts status prior to the Invasion from the North and of re-establishing the peace broken by the aggression." Leter policy displeyed much broader scope. 
FURTHER DEVELOPMENTS IX THE KOREAN AOTION ATD THE INTERVETTION OF THE

PEOPLE'S REPUBLIC OF CHIHA

Americen Intervention in Koree and Communist Reactone to the June 27 Resolution

On Wednesday, June 28, 1950 (Tokyo time), the headquartare of General Douglas Mecarthur in Tokgo announced thet the United States was actively Intervening In tho Koreen conflict. General HacArthur stated that a "amall advanced echelon" from his headquarters had been established In Korea, and that Far Fast AIr Forces and elements of naval forces under his command were conducting combat missions south of the thirty-alghth parallel. The operations vere "1n support of the Korean Republ10" whose government, the report stated, hed been roinstalled in Seovi after arnoured spoarheads from Northern forces had boen 1solated. The announcement from Tokyo also stated that four North Korean Plghters had boen shot down by United states planes when they had attempted to interfere with the evacuation of women and chllaren dependents of several znited states Mlasion from Kimpo alriteld, near seoul, operations of Amerlcan forces were apprently restricted to activities south

This is from newspaper account. It nocessarily lacks the precioe description which could be obtalned from confldential milltary records. 
of the thity-eighth parallel. On June 28 the initial drive into South Korea had apperently been checked.

President Truman's order of assistance to the South Korean forces was promptly reported in the Sorlet newspeper, Prevda. According to June 28 Lond on account of lioscow broadcast, Pravda had agld that "the Truman order signified that the InIted States Gorement hes taken a direct act of aggresion against the Korean peoplels democratic republic and against the people's republic of china." ${ }^{2}$

Phe North Korean government continued to assert its original position. that the south Korean forees had precipltated the attack. According to reporta, avallable to the New York Times, Premier Kim II Sung accused President Syngmen Rhee's government of texing the people to point of starvation in order to bulld up 1 ts war potential, and Theo wes blamed for "fallure to unffy the country peaceably." The democratic front in North Korea had made several propose is for unifleation, the last of which had been issued on June 7 . As for the Unlted Wations declalons, the government of North Korea issued a statement that they wore 11legal: first, because the Democratic People's. Republ10 of North Korea had not been represented when Its affars had been discussed; second, because the Soviet Unf on and (Communist) Chine had not participeted in the security counc1l doliberations.

New York T1mes, June 28, 1950, p. 1, col. 5. Ibld.. p. 18, col. 4. 
On the seoond polnt, the North Korean statement observed that the United Hations Charter required unanimity of the 1

f1ve perment members on tters of substance.

A Ithough reports from Tokyo on June 28 had given hope thet seoul could be saved, on June 29 Tokyo announced that Seoul had fallen to the North Koreans the day before. Tokyo 2.1so announced, on June 29, that the South Korean Army had rellied below the river south of Sooul with the ald of "owarming Pleets of United States warplanes." ${ }^{2}$ on June 30 , President Truman athorized the use of Unt ted States ground forces to repel the invaders in South Koree, the use of United States military alrcraft againat military objectives north of the thirty-olghth paral1el, and complete blockade of the Korean coset by the ravy. On the same dey 1t was reported that the South Koreans had virtualiy given up fighting after North Korean tanks ha broken through thelr defense at the River, outside of Seoul. Ameriean troops (estimeted at 1,000 ) were flown into Pusen, far south of the bettleline, In order to bring future holp to the South Koreans.

\section{The affer of Chinese Nati ona llat Proops}

$$
\text { Ior Kores }
$$

On June 29, the government of the Republ10 of Chtne

New York Plmes, June 28, 1950, p. 1, col. 6. Ibld., June 29, 1950, p. 1, col. 6. 4 Ibld.. July 1, 1950, p. 2, col. 4. I01d., 001.8. 
had recelved comunication from the Secretary General of the United Nations requesting it to furnish assistance to the Republic of Koree in accordence with the resolution passed by the Security CounelI on June 27. The Oninese Nationalist government accordingly offered, on June 30, to supply 33,000 troops, to be ready for embarktion in P1ve daje. The United States government held that, In light of the threat of invasion of Talwan (Formosa) by Cominust forces from the meinland, it would bo desirable for ceneral macthur's headquarters to hold discussions with the chinese military athortites on twan regarding 1ts defense prior to comitting any of Its troops to Korea.

\section{Continuation of the Conflict in Kores}

The defenses south of seoul crumbled before drive by four Horth Korean columns. It was reported that at least two of the columins were led by taniss, and that the situation on the front had become sertous. General MacArthur's headquerters anounced that Brit1sh and Untted States naval forces off the st cosst had sunk f1ve or s1x North Korean 2

motor torpedo bots. On July 4, it is reported that American troops had gone into action for the first time on the night of July 3 .

Hew York Times, July 3, 1950, D. 3, col. 3 . Ibld., p. 2, col. 8. Ibld., July 4, 1950, p. 1, col. 8. 
The North Korean government sent a bitter protest to the United Nations, charging that American intervention had obstructed the unity of the Korean poople, but that in spite of this intervention the Korean people would rally under the banner of the Korean Poople's Democratic Kepublic in their "holy war for the freodom, unity and independence of their native land." 1

on July 5, the Tokyo reports indleated that the strugele for South Korea had begun in earnest, with Inited State soldiers levelling an artillery barrage egalnst a North Koroan tank-led thrust and "considerablo naval activity" in the east, on the North Korean bridgehead in the Samchok area. On July 7, 1950, the U.S.S.R. charged in note sent

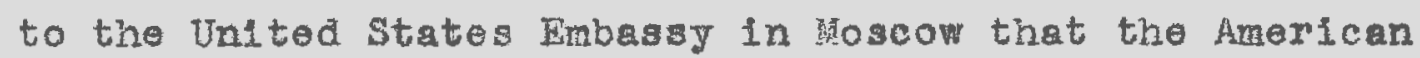
blockade of Koree was a "new act of aggression." The Kussian note was in reply to one sent by the United States, on Julg 4, which had informed the U.S.S.R. that the United States had establishod a naval blockade of Korea, "In keeping Ith the United Nations Security Council's request for support to the Republic of Kores in repelling North Korean Invaders and restoring peace in Korea. ${ }^{3}$ In 1 ts reply the soviet government stated that it would consider the Government of the United States responsible for ang damage to its interest which might be

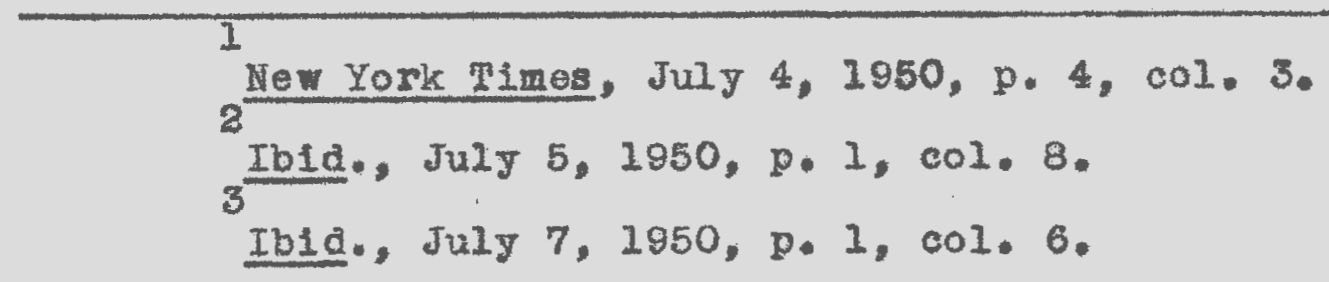


caused in connection with the blockade. About the same time It became apparent that the United States government was intensifying 1ts effort to prevent shipuents of 011 and other ver materials from resching Eorth Korean sympetrizers. In keeping wh the increased United Nations particlpation in the Forean conflict, a move was made to ostablish a unifled command under the leadershlp of the United States.

\section{The July 7 Resolution: The Recomendation for a Tnlfied Command Under the United Btates}

When the Security Council met on July 7,1950 , France and the United KIngdom Introduced a resolution designed to coordinate the assiatance which the Security Councll had recormended in the resolution of June 27 . Whe new resolution recomended "that all ifembers providing military forces and other asgistance pursuant to the aforesald Security Counc1I resolutions (June 25th and June $27 \mathrm{th}$ ) make such forces and other assistance avaliable to a unifled comand under the Unfted States." It further recommended that the Unfted states deslgnate the comander of such forcos, and requested the Jnited states to furnish eppropriate reporta on "the course of action taken under the unified command." ${ }^{2}$ In addition. the unfied command was authorized to fly the United Nations Plag, at its discretion, together with the flege of the other

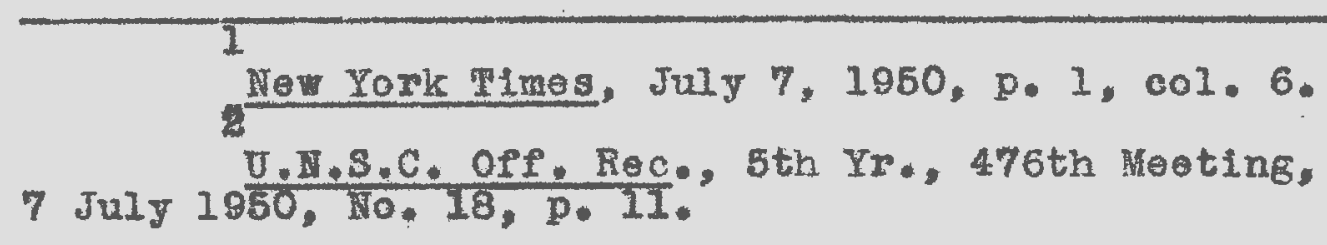


nations particlpating in the operetions agalnst the North Korean forces.

\section{1}

S17 G1adryn Jebb, of the United K1ngdom, spoke in favex of the regolution and gave a bumary intended to

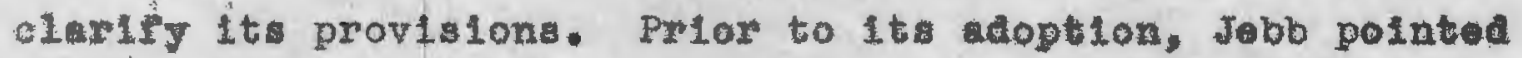
to the alfreuties of complying vith the provitiong of Article 48 of the Unitod Netions Charter. affleult 10 derived frow the fact that the prior miltary agreement between the socurity comeil and rember, stater, which were to provide the fomer 1 th power to anforce the vecurity provtelon of the Gharter a envisaged In Articlo 43 hed

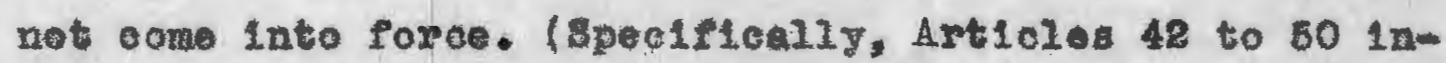
cluelve are those which outline "astion to be taken by a1r, cea, or Iand forces as any be necessary to maintain or reatore international peabe and securlsy under the direction of a M111tary staff comittes" dram from the "Chiefe of State of the pormenent members of the security coune13 or their reprosentatives." Jebb atated that sinoe a niffled command was essential if confusion were to be arolded, and sine the Charter had not cone. fully into foros, the council could meturaly act onty under Artiele 39, which enables the secur1ty Coune11 to repomend vint messures should be

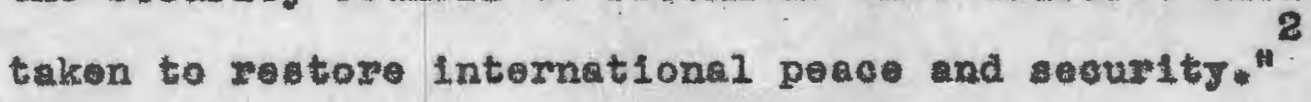

$$
\begin{aligned}
& 2^{1} \text { New York times, July } 8,1960, p, 1,001,4 . \\
& \text { U.N.S.C. Off. Rec, sth Ir, } 476 \text { th Moeting, }
\end{aligned}
$$
7 Jul. $1950,10,18,00.3-5$. Jebo malntalned that the "neossary recomandations vere duly rade in the resolutions of 25 and 27 June, but in the nature of thinga the cond onl be recomendatione to individual Members of bie inited 
The Franco-British resolution with respect to the oreation of a unfied command wes adopted by seven votes to none, with three abstentions, and one member absent (J.S.S.R.). India joinod Fgypt and Yugoslavia in abstaining. None of those abstaining offered any comment on the resolution at the time of its edoption.

The representatives of Nationalist China and of the Republic of Korea both gave supporting speches to the resoluIon of July 7 . which established unified command. The delegate of Nationalist China called attention to the Japenese war of aggression on China, which had begun on July 7, 1937 and which the League of Nations had falled to cheok. In

Mations. It could not therefore bo the UnIted Hations or the Security Council which themselves appointed a United Nations commander." According to Jabb, the function of the unified command wes "not an operative one"; all 1t could do was to make sure that the individual efforts of the sembers concemed were properly coordinated. Jobb based the function of the unifled command on Article 39 of the Charter. But Articlo 30 provides for security Councll supervision over both measures involving the use of amed force and those not lavolving the use of amed force. Those Involving the use of armed force are provided for in Anticles 42 to 50 inelustve, while those not involving the use of armed force are provided for in Articles 40 and 41. One of the main functions of these Articles under Chapter VII of the Charter is to differentiate clearly between measures involving the use of force and those not requiring 1t. Under all the Articles from 40 to 50 inclusive, both those involving the use of forco and those not involving the use of force--such as the severance of diplomatic relations, etc.-the Counclits resolutions aro regarded as declsions; and as such become mandatory for the parties concerned. The only portion of Chapter VII devoted to reconmendations is Article 39. Recomendations by the Security Council are made under Chapter VI, Pacific Settlement of Disputes, and recomendations mentioned in Article 39 of Chapter VII would seem to refer to twilight zone between Chapter VI and Chapter. VII, in which the use of the coercive aspects of the latter Chapter could be avolded if that wore desired. The logal aspects of srticle 39 are discussed in Chapter VII of the thesis. 
pleading for the support of the resolution before the Counc11, Mr. Fisang reminded the delegates of the heary price pald by. the Eeague's fallure, and stressed the logle of the adoption of the realution for a unlfed comend to reper the agreasion in Korea. ${ }^{1}$ The delogate of the Ropublle of Kotea, in a speoch lumediately following the adoption of the realution, deseribed with gat emotion the herolen of the Rorean people in what he ealled the bloody battlo against rlolent Commulst armed aggresston. He compared the attack of June 85 on his eountry vith the naked aggression on Polend and Poarl Ferbor. The representative of the Unitod states (Anstin). stated that the United stgtes would accept tho olg and spectel responsibilities laposed npon her by the rosolution. The "dastardly outbreak" (In Zorea) had made an "1saue of froedom of slavery" out of what appeaced on the durface to be a small matter, and the Unitod states would continue to dis. charge boy obligations as a Nember of the United Natlans in carrying out the resolution ostablishing a unfled comand under the Unted States. 3

The Unifled Comand in Operation

On July 8, 1950, President trumar named Geacral Bouglas NacArthur as tho comander of all Unlted Hatlons 1 U. H.S.C. Off. Roc., Bth Yr., 476th Moeting, 7 suly 1850, No. 18, D. 6 . 2 Ib1d. pp. 8-10.
Ib1d. pp. 10-18. 
military forces flghting in defense of the Republic of Korea. Generil illachrthur, hithorto coarander of the ocouption forces In Japan; thus oxtended hil comand to Include Eorea, under the July 71 recomendation of the security Counc11. on July 15: 1950, Prealdent Symgutan Fhoe of the Republle of Korea plicel all the Republic of Rorea's armed forces under. the Supromo Commander of the Unftod Nat1ons Forea, and on July 25; 1950 (Korean date), the Oeneral Hedquarters of the Uaited Nations Commañ was ostriblianed in Fokgo. At the next meeting of the Security Counoll after the adopton of the July was subaltted to the Counc11 by the Inited States Coverment. The report stated that at "0400 Korear t1we on sunday, 25 June 1950, the North Korean Aray launohed a conpletely unpzovoked Invesion of South Roran" After a description of the attacks lounched, the report steted that from the size and character of the attack it was ind1cated "oloarly that the 1rivalion had beon earefulig planned long in advance " ${ }^{2}$

The Retum of the U.S.S.R. to the Security Counc11, Angust I, 1950

On August 1, 1950, the representatlve of the $8.5 .3 . M$. roturned to the Security Councll to preside as its Prealdent

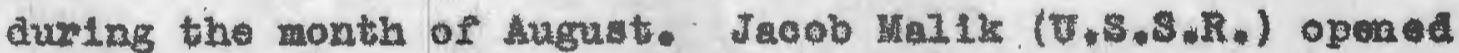
the noeting with a presidentiel ruling to exclude the reprom New York Times, July $0,1050, \mathrm{~g}, 1,001.5$. U.N.S.C. Off. Rec.. 5th Yr., 477th Hoet1ag, 25 July 1950, 10. 19, pp. $2-9$. 
sentative of the "Kuomintang group" from tho Council. H1s ruling was Immediately challenged by Austin of the Inited States, and the councll became involved in a heated debate over the issue of the Chinese representative on the Counc1l. India and Yogoslevia supported the President's ruling, but It was overridden by the other eight members of the Counc1l. The President then engaged in controversy with the American representative over the counting of the vote during wich the Fresident finally agreod to include the vote of the "Kuomintang group" in the count.

Mir. Malik then endeavored to have the Coune1l adopt a provisional agenda which contained these 1tems: "Recognition of the People's Government of the Poople's Republic of Chin as the representative of China," and "Peaceful settlement of the Korean question." After several meetings, during whioh long epeches were read by the representative of the U.S.S.R. citing the doeds of destruction boing perpotrated in Korea by "the ruling circles of the Unitod States," a vote was finaliy taken on the provisional ggenda. The item concerning the recognition of the representative of the Poople's Ropublic of China was rojectod with five in favor, five agalnst, and one abstention; and that concerning the peaceful settlement of the Korean problem wes rejected with only three votes in favor.- A thira item, "Complaint of aggression upon the Republic of Korea," submitted by the UnIted States, was adopted;

U.H.S.C. Off, Ree., 5th Yr., 480th Meeting,

1 August 1950, 10. 22, pp. 1-10. 


\section{$-57-$}

and the Couneli moved on to diserss this item at lts next meoting. The U.S.S.R. delegate relterated his charge that any ilecusion without the partiolpetion of a pepresentative of the People's Republic of Ghine was 111 ogal.

\section{M111tary Aetivit1os in Torea: \\ Retroet and Counter orfensive}

The Security Counc12 then engaged in hostod dobate over the logallty of the varlous resolutions adopted on the Forean problow. These resolution concerned the question of the recogaltion of the representative of the Poople's Ropublic of Chine, the participation of reprecentatives of Hoxth Korea In the Council discussions, the "eomplatat of bombings by Untted states airplanes of the territory of chind and the couplaint of the armed invasion of Taivan (Formese)."

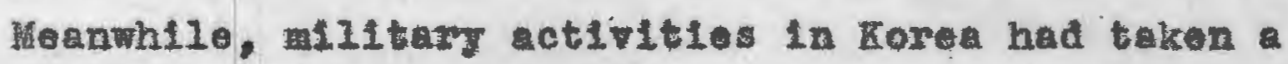
sudien turn. During the months of July and Auguat the forces alding the South Koreans had been driven Into retreat. As thoy began to rocover, act1ve preparations were walo for a counter offensive. A pectacular landing of 50,000 Marines and infentry at Inchon, near Seoul, on September 15, 1950, marked the beginning of the counter offensive. whe North Iorean Arwy had wom 1tself out in Indecisive attacks, and by

\footnotetext{
1

U.N.S.C. Off. Rec. 5th Ir., 488nd Westing, 3 Auguat 1950, No. 24, pp. $22-25$. 2 PP. $=6-98$

Ib1d*, 497th Meet10g, 7 Septenber 1950, No. 39, pp. $20-44$

Ible*, 503rd leeting, 26 September 1950, Ho, 46,
} 
a rapia serles of moves, Ceneral Macarthur's forces turned the Horth Koreen resistance into a rout. The result was surpriaing. By October 1, 1950, the Untted Hations wore treed with a deelsion as to whether their forces should exoss the chirty- Ighth parallel into North Torea;

Accordingly, a wolution wa latiodved in the General Assombly's Pollticel and soaurity Comitteo (Firat Comittee) which asked for a recommendetion thet "all appropriate steps be taken to onsure condition of atability through the whole of Korea" and "that all constituent acts bo taken including the holding of elections under the ausploes of the Jutted Nations, for the esteblishment of anifiod, independent and dowoeratie government in the covereign state of Koroa. ${ }^{2}$ Ceneral ihacArthur, In an open statement. "to the Comander-1nChlef of the North Korean rorces, "ealled on the North Koreans "to lay down your arms and coase host111ties" and to accopt "suob military supervision es I may direct." Ho mention was made of the politicul issue lavolved or the thipts-eighth para11e2.

On October 4, the Pollticel and Security Comaltee cast a 47 to 5 vote in favor of as elght power rosolution giving indiroct authorization to General MacArthur to oross the thirty-eighth perelzel. The resolution was schoduled to go before the Assembly 1teelf on 0otober 6, with a clear

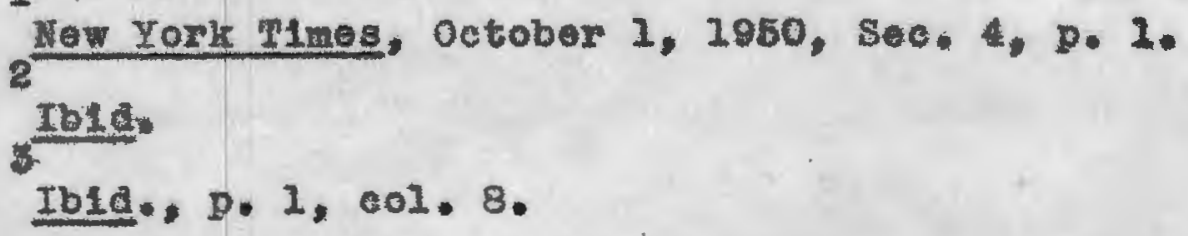


indication that it would bo adopted. The Politleal and Security Comittee rejected by a 46 to 5 vote the Sovietbecked resolution calling fors ceane-fire in Korea, imediate witharawal of foreign United Nation troops, and then electlons to bo organized by North and South Koreans.

On October 7, Folgyo announced that South Korean troopt hed crossed the thirty-olghth parallel ix force the day bester (Oetober 6th Korean time). In How York, the Generel Asetibly, on Ootober $7 \frac{1}{\mathrm{~b}}$, voted 47 to $5 \mathrm{wlth} 8$ abstentions to adopt the rosolution for unification of Lorea by "all appropriate atops," thus glving its indirect support to the military advances across the thirty-elghth parallel, Tolryo announced that American ground forces had crossed the parallel for the first time in the Korean war at $5: 14$ Poll. Ootober' 7 ; Korean time (3114 A,K:, October 7th, Eastern Stendard Iino), In order to reconnolter the enery positions." Thus, some Americen troops had orossed the thirty-elghth parailel a few hours before the General Assembly put its final approval on tho resolution for the aniflcation of Korea by "all appropriate atepa." On

1 Iow the resolution whlch was adopted on ootobor it. formance necessitated the use of United Nations forecs north of the thirty-elghth parallel.

8

Inle., 0otober 6, 1950, P. 1, 601. 8.

Ibla., October 8, 1950, p. 1, col. 6, See also U.H.G.A. Off. Rec.. 5th Sess o, Supplement 20 , Resolutions adopted by the Goneral Aosembly during the perlod 19 Septomber to 15 December 1950 , pp. 9-10.

4 Ib1d.. p. 2, 001.8. 
October 0, 1850 (Tokyo date), Generel HacArthur, in an vltimatum addressed to "the Premier and Government of North Korea," called on the North Koreans "for the last tiwe" to lay down the1r arms and cease hootilities. Ee warnod the Worth Korean government that unless it anowered Imwediately he wovila have to prosesd at once to "take auch all1tary action as may be nocessary." The message was broadeast nrom seoul and with it the text of the United Nations resolution recently passed by the General Assembij. ${ }^{2}$ No answo appeared to be fortheouling, and the war raged on.

\section{The Intervention of the Poople's Republic of ohing}

Conoral Machrthur's forees prosecd northward, and as they neared the Yalu River separating North Korea from Manohuria thoy met stiffened resiotance. Nevertheless, it appeared, at the beginalng of November, that the military phese of the Koreen war would soon be over. Suddenly Chlaese Communists poured across the Yalu RIver and brought advances to a standst111. On November 3. Fong Kong reported that

\footnotetext{
1

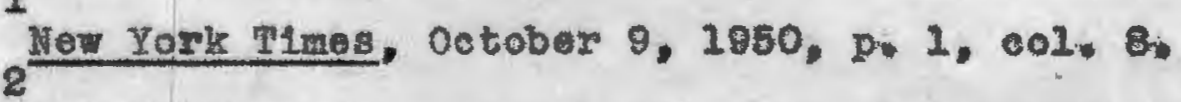

The Chinese Communat bulla-ap in North Korea probably atartod about ootober 16. In a special report aubaltted to the security Counc11 on 6 November 1950, General. NacArthur mentioned the movement of Cnincie Communist troops across the Yalu RIver on October 16 and Detober 20 . These troops proceeded Into Iorth Korea to take position near tho Chosen, Fusen, and SuI-Ho Dams. KE,H.S,C. Off, Rec, 5th Ir., 518 th Mooting, 6 November 1050, No, 60, DP. 4-5i.
} 
an all-out propaganda caxpalgn was bolng vaged in China in ordez to gain public suppert for a mor activo partiespation by Chinese Commutsts in the Rorean war. Premier Chou le-ial (Poople' Repubile of China) had declared in apeoth on September 30 that the Pelping reglwe would not "apinedy tolerate a crossing of the thirty-01ghth parallel by the United Vations forces. The propagand campelgn was largely doment, howover, unt1I the United Natlons foreos bogar to 1 near the Manchurian border.

On November 6 (Tokyo dete), Genoral MacArthur 1saued anited Nations cownunique on "latervention" in the Korean war. In the cownulque he stated that the Xorean war had boen broaght to a praction end unt1l the Chinese Comanintets had noved large numbers of forces across the Yalu Hitrer Into Horth Korea. Hang Kang roported on November 5 , that all the partide particlpating in the Cowarenist-dominated. Pelping coalition governmont had 1ssued formal doclaration glving full support to those Ohinese who "rolunterily under-

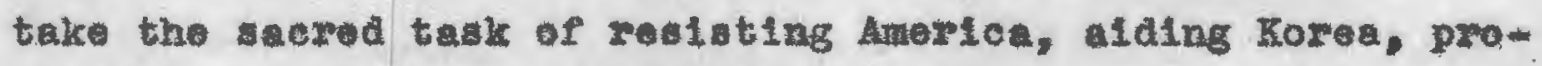
tooting their homes and defending thelr country." The statement maintained that "positive cetion" was nocessitated by the United Nations move across the thirty-elghth perallel and the advances of lerge forees tomard the Yalu River

$$
\begin{aligned}
& \text { New Yorik T1mes, November 4, 1050, } 0,3, \text { col, } 2 . \\
& \text { Ibla., Korember 6, 1950, p. 5, col. } 1 \text {. }
\end{aligned}
$$


boundary between Korea and Manchuria. The Pelplng declaration dainteined that the

United States Imperialist. are copylng the old trlok of the Japanese bandits--firat Inveding Korea and then Inveding China. Evergone knows Rorea is a small country, but that its strategic pestion is very important. Just as with the Japaneso imperialists In the past, the main objective of United states aggression on Korea is not Korea itself, but China. Ilstory shows that the existence of the Koxoan Poople's Ropublic and 1ts fall, and the security of or danger to China are closely intertwinod, 1

Maintaining that United Nation forces had 1 gnored Polplag's "warning". by crosalng the thirty-alghth parallel and puahing toward China, the statement insiated that Communist Chinn vanted peace and added:

Wo hold that the Korean question should be solvad in peaceful way and that the cespessive forees of the lmperlalists should be withdrem from Korea.

The Korean problem had entered new phase. The Intervention of the People's Republie of China dempened the ardor of those who had Flsulized United lation supremacy throughout all Korea and the flrm precedent that would have boen establiahed by the action of an international authority capable of helting the unsanctioned use of armod foree.

2 Ier York T1 res, Novomber $6,1050, \mathrm{p}, 2, \mathrm{col} .7$. Ib1d. 
THE AMERICAN VIEW OPPOSED; THE POSITIONS OF WHE PROPLE'S RRPUBITC OF CEIXA

AND TFE J, S. \$.R.

The Invitation to the People's Fepub11e

of China to deet rith the

Security Counc11

The Intervention of the Chinese Comunis to changed the natare of the war in Korea. The event was of sueh profound signiflaance that the Securlty counel1 proceoded immolately to consider the extension of an invitation to the Poople's Repulile of Chine to send a repreaentative to the Council in order to state that country's vievs. When the Counc11 met on November B, 1950, to consider the quetsion, the United States represertetive was outspoken in his opposition to such an invitation.

Warren Austin rojectod the proposition that an invitation should be extended to the comnunist rogimo although this procedure would have been in accordance with the practice generally followed by the seourity counoll of hearlng all parties to a dispute in order to avold resolving controvera1er by violeneo. Instead, he malntalned that witnesses for that regime should be auminoned before the council to glve what explanations they could of the state of affalxs wioh 
had been ienontut.

The delegate of the U.S.S.R. took exception to Austin's remarks, maintalning that suoh worts as "sumen" or "call upon" were out of place in connection with an invitation to be extended to sovereign stato. Mal1x further sesertod that the apokesmen in question would ropresent the government of a country of 475 mililon lnhabitants; fact which gave perticulaz polnt to the principle that relations botween sovereign states should not be conducted in terms of orders or dictations.

After some further discussion, a rasolution proposed by the Unlted Kingdom was adopted by 8 votes to 2 , with one abstention. Commulst Chind was to send to the Counell a representative who would be permitted to particlpate in tho discussion of the spooial report of the United Nations Command 3

In Korea. The United states voted for the resolution.

The Combination of the Two Questions:

"Complast of Armed Invasion of Teivan (Formosa)" and

"Complaint of Aggression upon the Republic of Iorea"

When the Counc1l met on Noverber 27 , the Prealdent of the Gouncli had pleoed on the providelonal agende a twofold queation: "(a) Complaint of arined invasion of Taimen (Formosa)" and "(b) Complaint of agreasion upon the Hopulile of Zoxea."

U.N.3.C. Off. Fec., Bth Yr., seoth Meoting, 8 November 1950, Ho. 68, pp: 1-8.

8

To1.*. pp. 2-4.

Ibld., pp. 8-9. The epectal report was read to the Councll at the 518 th Meobing on November 6,1960, pp. 3-5. 
The delegate of the U.8.8.,R. Imedietely objected to the combingtion, stating, that the representative of the People's Republic of china not empowered to speak on the second 1tem, sinee his govermment did not peoogntse the Unifled Comand. Malik went on to explain that the delegate from Communtst Chlne we in Iew Yoxk not to answer tho Hovember 8 Invitation of the counoli, but in reaponse to an eariler Invitation extended in september. ${ }^{1}$ The earlier Invitation had been isgued in comection with a dscuset on coneerning the "ocmpleint of the arwed investon of Paiwan." With the earlier Invitation In wind, thl partioular weoting hed beon or 11 at the request of the U.S.8.R. to disauss abject (a)

The Chinese Communt st delegate hed been sent by his goverment to chergo the United States with Invaston of Ta1wan (Fomosa) and ggreasion in Korea, and to particlpato, If postble, In general discusstons of the whole gorean problem.

\footnotetext{
U.H.S.C. Rec., 5th Ir., 585th Yeeting, 27 November 1950, S/PV 525, pp. 1-10. The referene denoted (S/PV Be5) Indicates that the ource meterie 2 is derived from mimoographed reoodis of the Securl by Counc1l forwarded to the Univereity of Rhode Is land library by the Unt ted Nations. These mimeographed reoords serve in 21 ou of the finished offlelel Records, which have not as jet been sent to this $11 b x$. considered offleial as thoy have not yot been fully corrected. 2

I.N.S.C. Off. Rec., 5th I.., 506th Heoting. 29 September 1950, No. 48, pp. 3-5. On 29 september 1950, the Councll adopted a rasolution proposed by Ecuador which invited - representative of the People's Republis of Chin "to attend the meetings of the securl by Counc1I held after 15 November 1950 during the discussion of that Government's declartion rogaraing an armed invesion of the Is le na of Taiwan (Formosa)." There were 7 votes in favor, 3 against, and one abstention. The UnIted states roted agalnst the resolution.
} 
After much hoated debate, this procedure was finalig agreed to by the Soviet Union, and it was decided to let the delegate of the People's Kepublic of Ching atate his government's views under the combined heading orlginaliy proposed by the Preaident 1 of the Counc1l. Since then the Security Council has considered the two problems as aspects of a single problem.

\section{The Position of the People's Republic of Chine}

On November 28, 1950, Wu HsiumChuan presented the views of the Peoplets Republic of Chine to the Security Counc1l. F1rst, he protested against the continued seating of the representative of the "Chinese Kuomintang reactionary remant clique." Wu called attention to the fact that Premier Ma Tse-tung of the Centre I People's Government of the People's Republio of Chine had solemnly proclalmed to the whole world on October 1 , 1949, that, that government was the sole legel government to represent all the people of China. Since November 15, 1949, ho sald, hls goverment had been endeavoring to heve the Chinese Kuomintang delegates expelled, but these efforts had been obstructed by the United States in ap1to of the affirmative rotes of sixteen member states of the United Nations.

U.N.S.C. Rec., 5th Yr., 525th Meeting, 27 November $1850, \mathrm{~s} / \mathrm{PV} 525, \mathrm{p} \cdot \mathrm{TI}$. 2

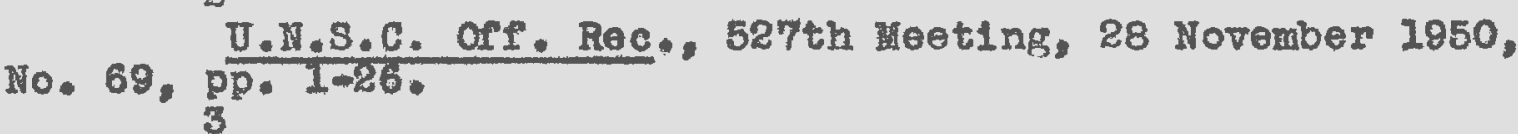

U.N.Q.A. Off. Rec., 5th Session, Plenary Heotings, Verbetim Records of lleetings, Vol. I, 19 September15 December 1950, p. 15. On September 19, 1950, India submitted 
Wu malntained that the people of China had no reason to recognize any resolutions or decielons of the United Nations without the participation of the lawful representative of the People's Republic of China, and once more called for the expulsion of the Kuomintang eroup.

Wu charged Prosident Truman with having instigated the "puppet Government of Symgman Fhee in South Koreq" to start the civil war in Korea. He then asserted that prosident Tmumen had stated on June 27 that the "United States Government had docided to prevent by force the liberation of Talwan by the Central Poople's Government of the People's Republie of China." To this end the Unitod States had begun her full-scale opon invasion of Talwan. Talwan, Wu continuod, was an inseparable part of the territory of China. He invoked 1 a United 3tates hite Paper to s:iow that the "native population for fifty years had been under the rule of a forelgn invader" and that during the occupation "the principal hope of the people had been reunion with the mainland." Wu charged the United States with having also violated China's territorial waters and territorial air along and within its coastine, by conducting active reconneisance and patrols. Ho called attention to atatement of President Tmaman on Jenuary 6, 1950 , in which he had declared that "the United states and the other a resolution wheh would have grented United Vatlons recognition to the Poople's Republic of Chlna. The resolution was rejected by 33 votes to 16 , with 10 abstentions. 1

J.S. Department of State, United States Relations with China, Publication 3573, p. $30 \overline{8}$. 
All1ed Powers have accepted the exerclse of Chinese authorlty over the 1sland," and to President Roosevelt's doclaration at Cairo on December 1, 1943, that Formosa should be restored to the Republic of China. Putting both of these claims together with the provisions of Article 107 of the cherter, Viu contended that the United liations had no right to a Iter the status of Talwan.

Wu went on to charge the United States with having followed a polloy of open Interventi on in China's internal affarg from 1945 to the present. He meintained that fumorican ald to "the Chlang Kai-shek Kuomintang reactionary clique" had made 1t possible for Chiang's government to launch a civ1l war a ganst the people whtch was unprecedented in Chine's history for its scale and cruelty. He stated that American troops stationed in Chine had perticlpated directly in the civil war and that the Untted Stetes and Chieng's government hed slgned "al1 kinds of unequel treaties and egreements Which reduced ching to the status of a colony and military base of the United States." On the besis of these treatios and egreements, $u$ charged, "the United Stetes Government secured my nal and air bases in Kuominteng china and gained control of the military, political, financial, and economic brenches of the Kuomintang Government."

U.N.S.C. Off. Rec.., 5th Yr., 527th Heeting. 28 Novemb 1950, No. 69, pp. 1-16. 2 Ib1d., pp. 16-18. 


$$
-69-
$$

Wa charged the United States with explofting Talwan ooononicaliy and advertod to alleged naval and milltary activities of the Unlted States and Chlang Kal-shek. He then asserted thet "the United States Govermment continues, through the Kuomintane remant clique, to try to prevent the Poople's Republie of China from 11berating TaIman, so that Taivan mey remain under the ectral domination of the United states. $n^{1}$

The American intervention in Telwan; continued Wu, sorved to prove to the Chinese people that tho United Statea viewed with host1lity the victories of the Chinese people. He stated that the intervention in Taiwan was not an 1solatod arfalr but an Intogral part of an over-all plan to ensiave the poples of As1a. He maintalned that Goneral MacArthus hed sevired Japanese fasclan and was uilug Japan as the heidquarters for aggression, In AsIa. Indece, the roroan wer was approeching so closo to Chla that China was only separated from the conflagration by asrrow river, so that her security was gravely threatened. Wu could not see, on the other haxd, how the security of the United states was jeopardised by the war in Korea whon the UnIted States was about 5,000 miles distant.

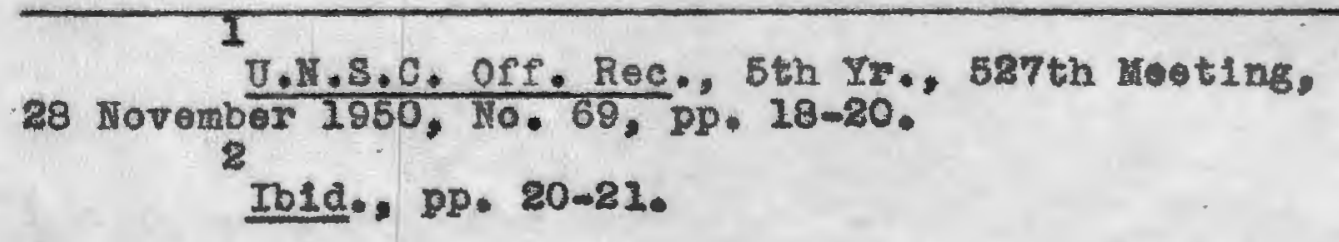




$$
-70-
$$

He asked the United lations Security Counell to condem the Unlted states for hor actlons and to take steps to atop American "amed eggression agalnst the territory of China, Taiman, and armed latervention in Korea." Secondi. he requested the Council to effoct the complete withdravel of United states forces from Thiwen, "in order that pece and security in the Pscific and in Asie mey be onsured." mintrily, wh asked that the Councll adopt measures to bring about "the withdrawal from Kores of the amind forees of the United States and all othor countries, and to leave it to the peoplo of Worth and south Korea to settle the domestlo affaire of Korea thenselves, so that a peaceful solution of the Korean question may be achiored. ${ }^{2}$

\section{The Position of the U.S.S.R.}

On Novenber 29 , the representative of the Sov1et Union geve a summary of the position of his government. MaII stated that since Anguat 3, the U.S.3.R. dolegation had produced documents and data to show that the erents taking pleoe in Korea had begun on Jun 25 as a reault of a provocative attack by the South Korean suthorities on frontier areas of the Korean Denocratic People's Republic. He further malntained thet the attack had been carried out in cocordanes with "previousiy thought out and prepered plen under the direotion and with the direct partielpation of United States

1 U.N.S.C. Orf. Reo., 5th Yr., 587 th Meeting. 28 November 1950, Wo. 69, p. 26. 
w11tary arisers, es well as with the knowledge of highly placed offleids of the United states....

The V.S.S.R. had pursued policy of peaco; its delegate stated, and, as early as hugut hed submitted a resolution asking tho Councll to "consider it noossary to Invite representatives of the Peoplo's Fopublic of China and slso representatives of the Korean people to ettend the discusalons of the Korean question in the Couno11." This resolut10n, moreover, had contalned a proposal to put an end to the host1litles in Korea and the same timo to withdraw forelgn troops from Korea." Malik contonded that furthes proposalo had beon edvanced in October by the dalegation of the E.S.S.R., whlek would have guaranteed declalon on the question of the Indepandence of Korea and a pereeful settlement. All these proposals, halik seid, wone rejected by the United States dologation and delegations of other countrlea which frequentis supported the unsted States. Celling attention to the Moseon Conference of Forolgn Miniaters in Decomber, 1945, he held that a docision had boen exrived at in that moeting which would bave rulig guarenteed the rehabllitation of Korea

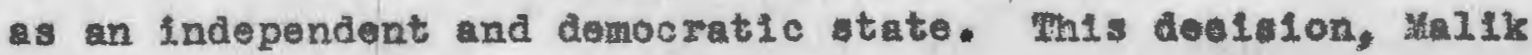
states, had been sabotaged by the Intted States government and the American comand in South Korea.

\footnotetext{
1 $1950,5 \cdot \frac{91 . N}{9}$

8/PV 528, 528th Neting, 29 Noverber
} Ib1d., pp. 92-94. 
Mal1k charged the Dnited States with having violated the Moacow agreement and taking the Korean queation into the United Hations in violation of Articlo 207 of the Unitod Nations 1 Charter, Ho argued also thet the Coumision's report to the United Natlons concerning the outbreak of host111t1es was unreliable and blesed, partloularly since it had been slgned by " representativo of the Kuomintang oalied Chu-Pu." Maliz then reltersted the position of the U.S.S.R. that the Security Couna11's realutions of June 25 and June 27 wero 1110 gal boeanse they were made without the partieipation of two permenent nembers of the Counc13-mb J.S.S.R. and China.

The Rusalan Aelegate cherged the Amerloan government whth having violated Internatlonal agreomenta by heving crosged the thixty-elghth parallel with military forces and advanced on the frontier of China. He claimed that the Tnited states before the Comanlst viotery had converted chine Into a colony by means of onslaving agreementa, end had alloonted over 5 b11110 dollars in the four post war yeare 1945-49 to ald Chlang Kal-shok to crush the liberation movement of the Chlnese people. Amerlean polley, he sala,

\section{1}

Article 107 states, Hothing in the prosent Charter shall invalidate or proclude ection in relation to any atate which during the socond Woxld Wer has boen an onoury of ans ignatory to the prosent chnter, takon or authoried as a result of that war by the governments having responsibllity for such actlon." Korea, of course, had been part of Japan durling the war.

\section{2 .}

U.N.3.C. Fiec., \$/PV 528, 588th MeetIng, 29 November 1950, $\mathrm{pp} \cdot 95-97$. 
was hostile to the Chinese people, and the selzure of Taiwan was a demonstration of this host1lity. Mallik maintained that President Truman's order of June' 27 , by which Ta1wan had been selged, constituted an act of eggression. The seizure, moreover, was in violation of President Truman's own tatement of January 5, 1950, that the Jnited states would not intervene In Formosa. Malik contended thet the armed selzure of Talwan covid not be "Unitod Hations action," sine President Pruman's order had been given pmor to any dec1010n by the security Coune11. Indeod, the Securlty covnell had not come to any deelsion on the selzure elther before or efter the order hed been given. Mallk oontended that there was no justifleation In treating the issue of Formosa as one whloh was intivately. bound up with the security of the Peclfle. The problen of Formos, he contended, was internal affalr of Chins, and the United Nations Charter pocifically berred interferenoe with the internal affairs of tates.

Finally; relik ateted that the goverment of the Poople's Ropablic of China had requested the U.S.S. R. to take urgent steps to require the withdrawal. of troops frow the territory of China and Korea. Accordingly, he urged measures to bring about such a withdrawal. 
LEGAL ASPECTS OF THE KOREAN ACTION

Pre-Cris 18 International Agreements Concerning Korea

The Korean problem has brought to the aurface a conflict of national interests in tho Pacific area. Changes as a result of the Second World War were foreseen by the participants, and, with the in of accommodating to these changes, number of agreomonts were contracted while the war was st1l1 being waged. In these agreoments, or treaties-the Galro Declaration of 1943, the Potgdam Proclamation of 1945, and the Hoscow Agreement of 1945--11es much of the -vidence of the legal atatus of Korea within the commity of states prior to June, 1950.

1

Herbert W. Brigg8, The Lew of Hationg (2d ed.s New York, 2952). On page 838 , Briggs cites tho Harvard Research to the effect that a treaty moy be defined as: "a formal instrument of agreement by which two or moro states establish or seok to establish a relation under international Inw between themselves." And on page 839, Briggs concluded that "the narrow use of the term "treaty' in American practice contins no implication that most of tho large number of executlve agresments concluded on behalf of the Unfted States do not have the jurldical force and effect of treatios in international law." (Since both the 1938 and 1952 editions of Briggs' work have beon used in this thesis, references to the $2 \mathrm{~d}$ odition $\mathbf{w l l l}$ hereafter be denoted: Briggs, 1952; reference to the firat edition will continue to be donoted: Briggs, 1938. 


\section{The Formation of Two Stetes: \\ Horth Korea and South Korea}

The Moseow Agreoment was contracted in order to prov1de moans by which the independence of Kores covild be achieved. When the United state became disatisfled with tho deadock produced in the Joint Commiesion and asked for a new four power moeting to bo held, 1ta proposal was rejected by the soviet Union. As a result, tho onited states took the question of Borean independence before the General Assombly of the United rations. What was the standing of the Mosoow Agreoment of 1945 Hed it become legally defunct following the refusal of the United States to continu working with the soviot Union under that agreement? Acoording to outomary 1nternational 1aw, the Americen interprotation of the Yoscor Agreement was only one interprotation and did not bind the soviet Unton or other parties to the agreoment. Was the Moscow Agreement volded by the cubmisalen of the question of Korean Indepondenee to the United Nations? The general practice of International lar argua againat such a result. This practice has $100 \mathrm{~g}$ Indicated "that when

\section{1}

Briggs, 1938, The David Jo Adame Case, 1921, po 441. Since the "rundamontal principle of the jurlaleal equality of states is opposed to placing one state under the jurisdiction of another state", it "1. opposed to the subjection of one state to an interpretation of a treaty asserted by anothor gtate. On page 446, in the Editor's Note, Briggs atates: - Ireaties may be interpreted authoritativeig oniy by the parties, ithor directiy through mutual agreoment or indirectiy by submission of the disputo to concliliation or arbitration by some international ageney or court mutually agreed upon and whose recomendation or declsion the J agree to accept." 
atate has bound iteulf by a treety with enother state, it oannot thereaftor rolleve 1 taelf of the obligetions it has aseunod by concluding a later tronty with another Ithird 8tate under whioh 1 assumes obligation: the performance of Whoh would Involve Impalment or repudiation of the obl1gation previously assumed." In the Moscon Agrecment four states had undertaken to provide for the setting up of a "four pores truateship of Kores for a peried of up to rith goes," and unilatoral doelsions to alter that agreement could int be binding on othes parties to the agreement. could the establishment of united rations comHWon on Korea set aside the Moscow Agreement and provido a hov mods of creating a Retlonel Governmont of Korea undar the alreation of the General Assembly It is alfficult bo Wh whe the United Nation could Find the authority whder 1ts phater to renounce the Moseor Agreonent, or to alter tho agreement to the extent that it could assort tho athority to conduct elections throughout Rores over the objocttous of one of the parties to the egreement. Jader

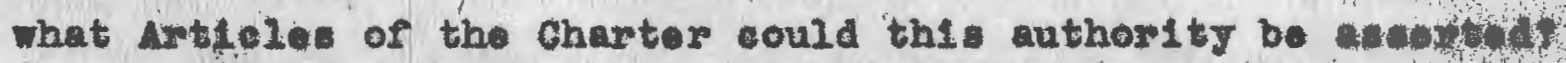

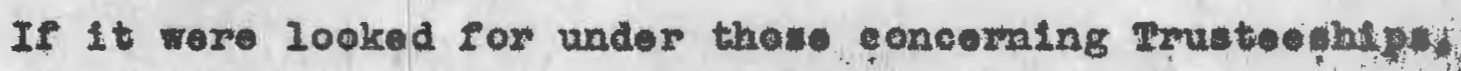
Artiole 79 would prevent al teration of torme of the truatec-

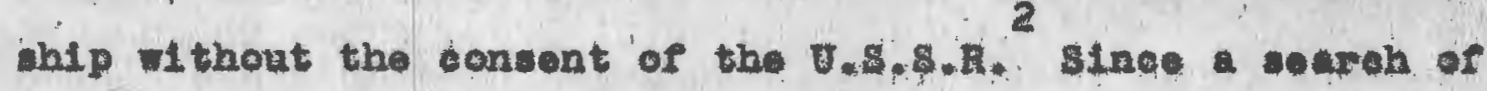

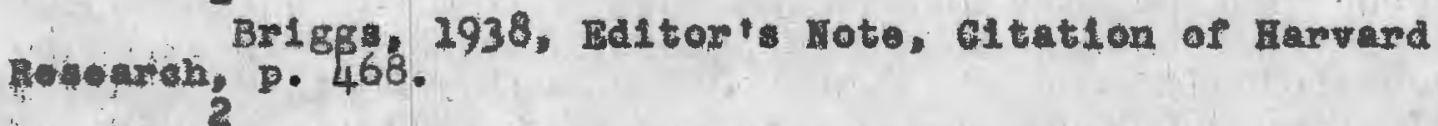

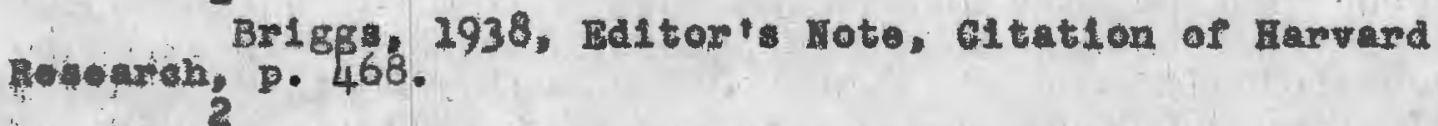

Article 79 or the charter atetes: "the tores of trusteeship for each territory to be plesed under the trustooship systom, including any alteration or amendment. shall be agreed upon by the states directly concemed..." 
the Charter fails to reveal any articlo specifically authorizing the Unitod Hations to and commision into a territory in order to observe elections, such power can only be implied. In the case of Korea the parties to tho agreoment drew different implications, and, as yot, no Impartial tribunal has authoritatively determined the competenee of the United Vations, or part of 1t, to enforee a decision of this nature upon disenting state.

The result of the separate elections in North Korea and South Korea was the establishment of two rival governments in Rorea. Both of these governments developed the attributes of statehood. Fach was organized and exercisod offective control over a defined territory. The independeneo of each was recognized by other states, although South Korea, was, In addition, overtly recognized by the United Nations and North Korea was not. Whatever differences international lawyers may have over the effect of recognition on the legal status of the states in question, thore was no doubt that both Korean Governments were physically capable of conducting tholr own international relations. Pinally, al though osch Government clalmed tho right to ropresent all of Koroa, each was the croation of a great power which was not likelg to allow 1ts protege, without protest at the rery least, to be divested of control of its territory. Thus, there 1s a good

1

Supra., pp. 25-28. 
basis for the position that two states were in fact created 1

from one Korea.

Status of the People's Repubile of Chine

How do the issues raised in the Korean problem

appear from the standpoint of the law of nations? Since the absence of the Soviet Union from the council because of a afference of viow on the question of the representation of Chine in the United Nations, the status of the People's Republic of Chine has become of increasing Importance. On March 8, 1950, the Secretary-Ceneral of the United kations circulated a memorandum to the mombers of the security Council which commented on the legal aspects of the problem

The writer feels that the guccession of events in Korea from the time of the elections of May 10, 1948, on, created so many distinotions between Horth Korea and South Korea, which were 11 kely to become permanent characteristics, that two separate states came into being. The holding of separate elections in the Forth and South was one step. Another was the stipulation of the United Hations Commisalon on Korea in 1.ts report to the General Assembly that Meraber States should take into account the limitations of the Jurisdiction of the Republic of Koree in establishing their relations with 1t. (Supra., p. 27) The formation of a separate govemment in the North and lts rocognition by the Soviet Union and other atates created another distinction. The Ilmitation which secretary Achson announced had boen pleced on the use of American armed forces (to restore the Repubile of Kora to its "status" prior to the invasion from the North) was still another. (Supra., p. 45) Finally, the ultimatum by General MacArthur addressed to the "Premier and Government of North Horea," before h1s forces orossed the thirty-elghth parallel, Indicated clearly the conditions which in fact oxisted. (Supra., p. 60) It is felt that those ovents and others show enough of a distinetion between North Korea and South Korea, polltically and militarliy, to warrant their bolng treated as two separate states under international 1aw. Th1s, of course, would not preclude an - ventual political union. 
of the representation of states in the United Nations. The memorandum held that the question of representation in the United Nations had boen Incorrectly linked with the question of recognition by the governments of momber states. The memorandur maintained that it would be appropriate for the United Nations organs to decide question of rival claims for representation in the United Nations on the grounds of ability to employ the resources and to diroct the people of the state concernod in the task of fulfilling tho obligations of mbership. If a revolutionary government prosented itsolf as ropresenting atate and was found to exereise athority win the territory of the atate and was hablually obeyed by the bulk of the population, these conditions should be sufficient to acoord it the right to represent the state in the organization.

What Secrotary-General Lie had in fact dono was to submit as critoria for seating in the United Nations the very criteria which treditionelly havo boen amployed by states for the purpose of according recognition to now governments. But in dolng this, he had avolded the question of whether or not United Mations recognition of a government, for the purpose of conducting onited Nations business, should be predicated upon a prior resolution of wother or not that

\footnotetext{
U.N.G.A. Off. Rec., Annual Report of the SocretaryGeneral of the Work of the Organization, 1 July 194930 June 1950," 5th Session, Supp. 1, p. 33. Article 99 of the Charter states: "The Secretary-General may bring to the attention of the security Counc1l any matter which in his opinion may threaten the maintenance of international poace."
} 
government attained logal status by virtue of third party recognition apart from the Untted Nations.

In the Tinoco Arbitration case (1923), the Arbitrator, Chiof Justice William Hovard Faft, hold that "tho change by revolution upsets the rule of the authorities in power under the then existing fundamental law, and sots aside the fundamental law in so far as the change of rule makes it nocossary." ${ }^{1}$ Also "The legality or constitutional legitimacy of a de facto government is without importance internationally so far as the matter of representing the state is concerned." ${ }^{2}$ The Tinoco decision made it clear that revolutionary government which had ostablishod 1 tself in such a way that "all within 1 ts influence rocognize its control" ${ }^{3}$ binds the nations, and "so far as its international obligations are concerned, it represents the state." 4 If one accopts the above criteria, he is obliged to conclude that the central Poople's Government of the Peoplo's Republic of China is the actual government of the mainland of China.

In Luther V. Sagor (1921), a British Court of Appeals held that "if the party seoking to dislodge the existing government succeeds, and the independence of the government It has set up is rocognized, then the acts of such government from the commencement of Its existence are regarded as

Iriggs, 1938, The Tinoco Arbitration, 1923, p. 120.
$2^{\text {Ib1d., p. } 117 .}$
${ }^{\text {Ib1d., p. } 120}$
Ib1d., p. 117.


those of an Independent nation. ${ }^{1}$ since the Central Peoplo's Government of the People's Republic of China was proclaimed to be the sole legal government to represent all the people of China on october 1, 1949,2 and since no effective resistance to dislodge it as the Government of China has been wtnessed since that date, under international law that Government should be regarded as the legal Government of China since Dotober 1, 1949.

Although international law would support the viow taken in the secretary-Goneral's momorandum to the securfty Coune1l in March, 1950, the various organs of the United Nations have preferred to take tholr stand in regard to Chinese representation on the ground of polftical expedieney. They have taken this view in spite of the fact that the Secretary-General had olted precedent within the united Nations itseif to the effect that there had not been aingle Instance of a challenge of the credentials of a sepresentative of a revolutionary govemment in the United Nations until the chinese question arose.

Amerloan objections to the recognition by the United Nations of the representative of the People's Republic of

\footnotetext{
1 1921, p. 201 .

Br1ggs, 1938, A. M. Luther V. James Sagor Co., 28 November, 1950, 10. 69, p. 3. 3 . 3

Tren-L1-Liang, "Rocognition by the United Natione of the Representation of a Hember State: Criteria and Procedure," American Journal of International Lar, Vol. 45 (1951), p. 704.
} 
China rested on two major grounds. In speaking before the Ad Hoc Political Commlttoe, Ernost Gross maintainod that tho honesty and integrity of the United Nations was Involved in the recognition of new regime. He contended that "even in applying the criterion of control between two competing regimes, the question whether the poople freely accepted - 1ther or both regimes might be considered in determining whether of ther regime had real control over the state." He also felt that "the purposes of the United Nations would not be furthered by lgnoring the fact that one or other of two compoting clalmants for accreditation was unwiling and unable to carry out the obligations laid down in the charter. The United States, therefore, ralsed two questions which would have to be met by the People's Republic of China before it would be recognized by the United States. Did the Chineso poople voluntarily accept their new government? Also, was the People's Republic of Chine willing to carry out the obligations laid down in the United Nations Charter?

\section{The Status of Formosa}

The wartime agreements also made provision for the future of Formosa. Under the Calro Declaration, Formosa "was to be restored to the Republic of China," and this decision was confirmed by the Potsdam Agreement. 3 But as a

U.N.G.A. Off. Rec., Ad Hoc Political Committen, Summary Records of Yeoting, 30 September-14 December, 1950, p. 120. 2 3 Supre., p. 16. Supra., pp. 16-17. 
result of the civil war in China, Formosa became the soat of Chiang Kai-shok's Nat1onalist Government after 1ts defeat on the mainland of China in 1949 and has continued so to the present day. To what country does Formosa then belong?

As noted by the Swiss Pederal Tribunal in Lepeschkin v. Gosswoiler (1923), "1t 1s a universally recognized and incontestable principle of the law of nations that modifications in the form of government and in the interlor organization of a state can have no effect upon its rights and obligations in international law; in particular, they cannot abollsh the rights and obligations resulting from treat1es which that state has concluded." ${ }^{1}$ Since Formosa was to be returned to Chine after the second world War, and was actually delivered Into the hands of Chinese Nationalist troops, what 1s Its status as a result of the Chinese Civil War? The Chinese Nationalist delegate in the Security Counc1l sald that "Formosa was looked upon by the chinese poople in the same light as the other provinces of China." At the same time, he sald that he was thankful for having the Amerlcan fleet protect Formosa from an attack from the People's Republic of China. From the statements of the Chinese Nationalist delegates one can only conclude that the chineso Nationalists have intended to use this protection in order to

Br1ggs, 1938, Lopeschkin V. Gosswoller \& Co.. Switzerland, Foderal Tribunal, 1923, p. 483. 2 Supre., pp. 40-41. 
gein the time and resources necosery to launeh a counterrevolution on the mainland of Chine. Acoerdingly, the Pormosan action taken by Prosident Truman would seom bost to be regarded as armed Intervention by the United states in the Chinete 01vil War. It 18 trae that there "1s no rule of linternational law which forbids the government of one state from rendering assistance to the estublishod logitimate govermmont of another state with viow to enabling it to suppress on insurrection against 1 te authorits." ${ }^{1}$ But w111 that rule oontinue to apply in this oase? It has alroedy been pointed out that the government in question is no longer establishod on the mainland, and that since Oetober 1, 1949, the Government of the Poople's Republic of China has been acting as the efrective government of China.

In all 11kellhood, the Truman order of June 27, 1950, prevented the Chinese Commulats from selang Formesa. S1nee that time the government of Formosa has been treated by the United states and many othor states as the legitimato government of China. Preservation of the ChInese Nationalists on the 181 and of Formosa, wh a definite territory and a delinite population under Its control, plus the recognition by many other states of the right to conduct Its own forelga relations, has servod to make Formosa a de facto state. Thus we may conclude that thore are actualiy two Chinas, one 11 mited Briggs, 1938, Editor's Noto, p. 744 . 2 Supra., pp. 37-38. 
to the control of the mainland, and the other limitod to

Fornosa.

It became apparent that the situation created by the

formation of two rival Chinese states who disputed the territorial limits of thoir respectivo jurisdictions would create a menace to the security of the Pacific area. In an endeavor to solve the problems created by this condition, the United States appealed to the United Nations. On September 20, 1950, the American Secretary of State, Dean Acheson, stated that American position before the General Assembly. Ho sald:

The aggressive attack upon the Republic of Korea created the urgent necessity for the military neutral1zation of the 1sland of Formosa. The President of the Inited states, in announcing on 27 . June the measures taken to effoct that neutrelization, emphasized that those measurea were to prevent mill tary attack by mainland forces lgainst Pormosa and by forces from Formosa against the mainland. The Prosident made it clear, at thet time, and he has made $1 t$ clear on several occasions ince, that those measures rere taken without prejud100 to the future political status of Fomosa, and that the United States had no territorial ambitions and sought no special priviloges or position with respect to Formosa.

It $1 \mathrm{~s}$ the bellef of my Government that the problem of Formosa and the nearly elght million people who inhablt 1t should not be settled by force or by unilateral action. We belleve that the international community has a logitimato interest and concern in heving this mattor settled by peaceful means. Accordingly, the United States delegation proposes that the General Assembly should direct its attention to the solution of this problem in circumstances in which all partios goncerned and interested have full opportunity to express the ir views, and in which all partios concerned agree to rePrain from the use of force whlo peacoful and oquitablo solution is being sought. We shell therefore request that the question of Formosa should be added to the agenda as a matter of special and urgent importance.1

U.N.G.A. Off. Rec., Plenary Heetings, Verbatim Records of Heetings, Vol. I, 19 September-15 December, 1950, p. 25. par. $63-64$. 
The Intervention of the People's Republic of China in the Korean War

Having come to the conclusion that two states had beon ereated in Korea, the question arises as to the legality of the Chinese Communist intervention in that area in Hovember, 1950. The argument could not be advaneed in this case that this was ald to the establishod logltimate government to crush an insurrection against 1 ts authority. As explained above, North Korea and South Korea should be considered as Independent states, and the war between them an International war, rather than elvil war. Thus, ald to one of the belligerents should be classed as ald to snother state, and so constitute intervention in an international war. The ectual Intervention of the Chinese Communists would seom to contradict an asaumption that the Koroan action was legel Security Counell enforcement measure. When the forces of Communist Ohine entered the rleld, a poworful Chinese army went into military battle agalnst an action supposediy ondorsed by the representative of China on the Security Counc11. Thls anomalous atate of affairs was brought about by a misepresentation of the Chinese state in the Socurity Counc11. To contend that the Chinose Nationalist delogate in the Socurity Couno1l represented the Chinese state, or its poople, for the purpose of enforcement measures, would overlook the conditions which existed on the Chinese malnland. 
Colloctive Security Through the Un1ted Hationg: Enforcement Heesures Agreed Upon at San Frencisco

At San Francisco the varlous ways in which enforcement measures should be taken in ordor to maintain or restore international peace wore discussed at length. Two majoe plens were developed. One entallod the placlng of prialary rosponsibility in the Socurity Counc1l. Its advocatos pointed to the inequality of power which oxisted in fact in the international community. Because of this inequality, it was pointed out, the major burden of onforeement measures would have to be borne by the great powers. This burden would fall primarily on the shoulders of the great powers for throe maln reasons: rirst, because the great powers had the greatest potential pesources for earrying out enforoemont measures; second, because the great powers were capable or earrying a larger proportionate share of the obligation per state: and third bocause colloctive action on the part or Iss powerful states would be Ineffeotive if opposed by any ingle great power. The experlences of many of the lesser porers in the Loague of Nations and In international arralre in general led them to question the degree of security they might bo able to expect from such an arrangemont. These states folt that the unanimity principle sare too much power to the alroady groat states--power whlch they might not dovote entirely to the mutual intereats or all. conderned. The lesser atates also reared that the great 
powers might not reach agreement and thus might 1eave the International organization powerless and ineffective in a time of need. AccordinglJ, they advocated a plan which would subject the Security Counc1l's decisions to revien by the General Assembly, in which no veto applied, states vere given an equal vote, and the decision of a two-thirds majority prevasled.

The lesser powers realized that the history of great powers lent 1ittle support to the view that great powera would be primarliy motivated by altrulatic principlea in conducting their international relations. They realized that great powers, as well as lesser powers, had their own national interests to promote and that the promotion of those interests was not always in the common interest.

Italy's aggression in Ethiopa, Japan's aggresgion in Hanchur1a, and Gormany's selzure of Austria were st111 fresh In the minds of many statesmen in the world. The lesser powers found it easy to viaualize the culmination of circumstances under which they might become defenseless if they were entirely dependent upon the unanimity of the great powers in order to have at tholr disposal a legitimate means of effecting thelr collective securlty. Although they granted the superiority of a system of collective security which would place at the disposal of the international commulty the combined strength and resources of the great powers, they were not convinced that such a unity would always prevall. The lesser powers were informed that under some extreme 
ciroumstances all the nations might have to choose among themselves whether thoy wished to go to war or not. The lesser powers were then confronted with two alternatives. The first was to place their trust in the great powers to act together to preserve the peace and to relg upon five great powers to act in unity in the common interest. The socond alternative was to insist upon additional methods or maintaining posce which would bo in addition to the unity of the five groat powers. At this point, the lesser powers were informed at San Francisco that any attempts to alter or supplement the five power formula might see the representatives of the lesser powers returning to their countries without charter.

After much dellberation, a compromiso was reached. The lesser powers would agreo to the unanimity principle if the General Assembly would be granted as wide a scope as possible while the Socurity Council was not actually considering an issue. In addition, the Charter was to be construed with flexibility, and in such a way as to allow the United Nations to develop by procedent. Pinaliy, the Charter was to be subject to amendment.

The great powers pledged a constructive use of the veto. The lesser powers agreed to place thoir trust in the great powers, wth the stipulation that the General Assembly be granted the widest freodom possiblo in its discussion and consideration of International affairs. In order to insure that all the powers would still have a forum in which they 
could speak on equal terms, the tochnieal committeo at $S$ an

Pranc1800, whlch was consldering the powers of the Goneral Assembly, made an interprotive declaration to this effoct, whloh was included in the permenent records of the conference. Thi declaration statod

The General Alaembly w1Il have the right to discuss any questions or any matters within the seope of the Charter or relating to the powers and functions of anj organs provided in the charter. It will be authorized to call the attention of the security Councll to situations likely to ondanger peace and securlty. When the gecurity Council in the discharge of 1ts special responsibilitios is dealing with a dipute or situation which may endenger tho pesce, the theneral Assembly cannot make recommendations on any such dispute or altuation. It 1s, howevor, lald down that the SecrotaryGeneral shall. With the consent of the security councli, notify the Assembly--or the members of the Organization if the Assembly is not in session--1mmediately the Socurity Council ceasea to deal with any such matters. In other respects, however, 1ts right of recommendation to the Security Counc1l, the momber states or both 1 s as broad as its right of discussion. It includes the Fight to recommend measures for the poeceful edjnstmont of any situation, regardless of origin, which the Assembly doems $11 \mathrm{kely}$ to impals the general velfare or friendly relations among nations; the right to make recommendations on the general prinelples of cooperation in the malntenence of international perce and security, Including those governing armaments and the regulation of armaments; and in addition wide povers of reconmendation in cocnomie, social, culturel, ind human1tarian matters.

The Assembly -111 be empowered to "recelve" and "cons1der" reports from other bodies of the Organisation including the Security Coune11. The reports of the Security council shall inolude an account of the moasures which it has taken to maintain international perce and security.

Commission II calls particular attention to the word "consider" as used in the Charter in connection with reports of the Socurity Council and other organs. It is the intention of Comeission II that this word shall be interpreted to encompass the right to discuss, and that the power of the Assembly to discuss and make recommendations as defined in Articles 10, 11, and 12 and 14 is not to be limited in any way with respoct to 
1 ts consideration of reports from the seourity councll. Commisaion II recomends that this plenary session approve this interpretive declaration of the comnission and include it in the permanent record of the conference. 1

The Pesort to Improvised Security Arrangements as a Result of the Failure to Achieve Great Power Unity

The unanimity prinelple agroed upon at San Prancisco callod for the negotiation of spocial agroements between the Security Counoil and momber states in order to make arailablo to the council the armed forces upon whloh 1 t was to roly, if nocessury, to carry out its responslb1l1ty for the enforce2 mont of collective security. The Charter also provided for the establiahment of a Milltary staff Committe "to adviac and asalat the Security counell on all questions relating to the seourity Counc1l'g militery requiremente for the maintenance of International peace and security...." This MI1tary staff Commlttee was to bonsist of the Chiefs of Staff of the perranent members of the Security Counell or thelr representatives." It was to be reaponsible "for the stratogie dirotion of any armed forces placed at the disposal of the security counc11. $n^{4}$ The collective security syotem onvisaged at San Pranc1sco was written into the Charter with explic1t

U.N. Conf. Intntnl Org. Vol. 8, Commission II (Ceneral Asaembly), Revised Report of the Rapporteur of Conmision II to the Plenary Session, June 24, 1945, pp. $266-67$. The weport wes approved without comment or objection at the Inth Plenary Session, June 25. 1945, U.N. Conf. Intental 0x: Vol. I (General), p. 623.

2

Charter of the Unitod Nat1ons, chap. VII, art. 43. 3 Ibld.. art. 47 . Ib1d. 
provision having been made for retention by the permanent mombers of the direction of any United Hations armod forees. It was foreseen that this system, based on the princ1plo of unanimity, would not com immodiately into force. Consequentij, additional provisions wore mado for the porlod between ratification of the Charter and concluaton of the special agreements necessary to give effeot to the enforcement moasures enviagged in Chapter VII. For this purpose Chapter XVII (Transitionel Security Agreomonts) was Inéludod In the Charter. Article 106 of this Chapter provided that:

Pending the coming into foree of such special agreements reforred to in Article 43 , as in the opinion of the Security Council onablo it bo begin the exerclse of 1ts responsibilities under Artielo 42, the partios to tho Four-Nation Declaration, 1 gned at Moscow. Detober 30, 1943, and Brance, hall, In accordance with the provisions of Paragraph 5 of that Declaration, consult with one another and, as occasion requires, with other members of the United Nations with a view to sueh joint action on behalf of the organization as may be necossary for the purpose of maintaining international poace and security. I

It may be seen from Article 106 that mosures ontallIng the use of armed force under Chapter VII of the Charter depend upon the conclusion of the apecial agreements mentioned In Artiolo 43 of the Charter. Since those apecial agroements have not as yot been concluded, It may be assumod that those Articles of the charter which depend upon the agreoment are 1noperat1ve. This renders Art101es 42 to 47 of the Charter Inoperative, and leaves Art1elos 48, 49, and 50 open to 
question, since the latter were origlnally written to accowpany the former.

When hostilities broke out in Korea in June, 1950, and the Security council found that its call for a cease-fire was 1 gnosed by the forces of North Korea, the United Nations wes faced with the task of lmplementing some poliey of colloctive socurity in order to restore international peace in the area. The Security Counoll therefore resorted to improviantlons in order to restore international peace. Two of these 1mprovisations were the resolutions of June 27 and JuIy 7 . Where in the charter could authorieation be found for, onforcement measures?

It has alroady been pointed out that the lack of the spocial agreements montionod in Articlo 43 of the Charter precludes the use of Articles 42 to 47 . Would Art1010 106 then apply According to the American interprotation of Art1010 106 expressed at San Frane18ce, "the Security Coune1l would delay in exerclsing its funetions only with respoct to those function whose performance would be impalred by the non-existence of appropriate apecial agreements under paragreph 5, section B, Chapter VIII." " since Art1cle 106 left

U.N. Conf. Intntl. Org., Vol. 12, Comission III, (Secur1ty Counc11). p. 534. The delegetes at San Frane1sco rovlsed the Dumbarton Oaks Proposals. The Dumbarton Oaks Proposals were arranged so tnat Chapter VIII bore the title: -Arrangements for the Malntenanos of International Peace and Socurity Including Provention and Suppression of Aggrosalon." Under Chepter VIII were threo sections: Section A, paelfie Sottioment of Disputes," Section B, "Dotermination of Threate to the Poace or Acts of Aggression and Action W1th Rospoet Thereto," and Section $C$, "Rogional Arrangements." At Sen Francisco Section A provided the basis for Ohaptor VI of tho Charter and Section B the besis for chapter VII. 
the determination of the degree to which it would be applicable up to "the opinion of the Security Counc1l," one would expoot the Security Council's oplnion to be the deciding factor in the use of Artiele 106. The security Councll ald not mention Article 106 at the time it considered the use of enforcement measures in Korea. Therefore, one could conelude that Artielo 106 was inapplieable.

\section{The only remaining article in chepter VII of the} Charter whioh could be used as a bals for authorlsing onforcement measures 1s Article 39. Article 39 of the Charter statos:

The Security Council shall determine the existence of any threat to the poace, breach of the poace, or act of aggression and shail make rocommendations, or doclde what moasures shall bo taken in accordance with Articlo: 41 and 42 , to maintain or reatore intermational peace and socurity. 1

since there had beon difficulty at San Francisco in dotermining the meaning of the word "recommendations" and also the word "moasures" as used in this text, an interprotation was dram up which met with the unanimous approval of the tochnical committee considering the drafting of what became Article 39 of the Charter. The interpretation observed:

(1) In using the word "recomendationg" in section B, as already found in paragraph 5, Section $A$, the Committeo has intended to show that the action of the council sofar as it relates to the peceerul settlomint of a dispute or to situations giving $r$ ise to a threat of war, areach of tho pesce, or aggresalon, should be considerod as governod by the provisions contalnod in section A. Under such an hypothesis, the Councli would in reallty pursue

Charter of the United Nations, art. 39. 
almultaneously two distinct actions, one having for its object the settlement of the dispute or the diffleulty, and the other the enforoesent or provisional measures, -ach of whlch 1s gorerned by an appropriate seotion in Chepter VIII.

(2) It 1s the Committeo's view that the power given to the Counc1l under paragraphs 1 and 2 not to resort to the measures contemplated in paragraphs 3 and 4 , or to rosort to them only arter having cought to malntaln or restore peace by inviting the partios to consont to certain conservatory measures, fofers above all to the prosumption in a throat of war. The Committeo is unanimous in the beller that, on the contrary, in the case of flagrant aggression imporiling the existence of a momber of tho organiation, enforconent asures should be taken without dolay, and to the full extent roquired by the clrcuastances, except that the Counc1l ahould at the same time ondeavor to porsuade tho aggressor to abandon its venture, by the means contomplated In section $A$ and by preacribing conservatory masures. I

As already montioned, section A of Chapter VIII of the Dumbarton Oaks Proposals becamo Chapter VI of tho Charter, and Soetion B became Chapter VII of the Charter. Applieation of the San Franc1sco interpretation to Articlo 39 of the Charter In a case of flagrant aggression would require that the Counc1l follow "almultaneoualy two distinct actions, one heving for its object the settlement of the dispute or the difficulty, and the other the enforcement or provisional measures." Thus, in the case of Korea, if the Security Councli should decide to involce Artiale 39 in order to euthorize enforcement measures, It would also be obligated to pusaue another course of action simultaneouely in the nature of recommendation under Chapter VI of the Charter and conservatery measures in an ondeavor to persuade the aggreasor to abandon its renture.

U.H. Conf. IntntI. Org, Vol. 12, Commisalon III (Socurity Council), P. 507. Articlo 39 vas discussod in conjunction with the establishment of a Unlfled Command on page $52-53$ of the thesis. 
$-96-$

When the Seourtity Gounoll considered the onforeement measures to be taken In Korea, no montion was made of Art1010 39. When Art1020 39 was mentioned in confunction with the establishment of the Unifled Command on July 7 , sir Gladwy Jebb, the United Kingdom delegate, made it clear that Artiele 39 was not belng invoked for 1 ts operetive 1 characteriaties, but, rather, in a proocdural senso. Wo my thus conolude that the couneli did not involve Artiele 39 In order to authorize enforcement measures agalnst North Korea.

One other course might be left open in order to provide bals for enforoenent meesures under chapter VII of the Charter. This course would allow the use of Artiele 51, but would be limited to collective selfmderense until the securlty counc1 1 had "taken the measures necessary to molntaln internatione 1 peace and securl ty." ${ }^{2}$ Nolther tho Unt ted States nor the other states providing milltary agalaturee to South Koren montioned Article 51 of the gherter in connection with the plens in the security Counell for furniahing this assiatanee. The United States developed the interpretation that authorization for enforcement meares could be found in Article 1 of the Omerter:

I Supra., pp. 52-53.
2 Charter of the United kations, art. 51.


The Borean Action: An Erfective collective Messure under Article 1 of the Charter

The American action In Korea was described in the

General Assembly by the American Secretary of State as an effective collective measure under Artiole 1 of the Charter. Th1: Art1elo states:

The purposes of the United Irationa are:

1. To maintain intemetional posce and steurity, and to that ond: to take effoctive collectlve moasures for the prevention and removal of threats to the poses, and for the suppression of acts of aggression or other breaches of the peace, and to bring about by peaceful means, and in conformity with the prinolples of justice and Interantional law, adjustment or sottlement of international disputes of stuations which might lead to a breech of the pence....

It is obvious that this is a foundation artiole of the Oharter and clearly donotos the intention of the partion. Acoording to Brierly, "there are no technical males in internetional law for the interpretation of treatios: its object can enly be to give effect to the intention of the partio: as fully and fairly as poselble." ${ }^{2}$ Thi view 18 also axpressed by the Harvard Researeh, which states that "the function of Interpretation is to discover whet was, or what may reasonably be presumed to have been, the intention of the partio to a troaty when they concluded 1t, and that this is to be accomplished by the application of certaln males of log1c and gramar to the instrument 1 tse If." ${ }^{3}$

1

U.N.Q.A. Off. Rec., Plenary Meotinga, Verbatim Rocorda of Hoetings, vol. I, I9 September-15 December; 1950, p. 24. 2 p. 234 . J.L.Brierly, The Lat of Nations (4th d. London, 1950), 
It 1s obvious from a study of the preamble and the main text of the United Nations Charter that the purpose of the algnatories was to provide a system of collective security. The preamble states that the peoplos of the United Nations are "to Insure, by the sccoptance of prinelples and the institution of methods, that armed force shell not be used, seve in the common Interest..." North Korea attempted to Impose 1 ts w1Il upon South Korea by armed foree. A Onited Nations Commission determined that the Horth Korean attack was unprovoked and was assuming the proportions of a full-acale war. The Socurlty Gouncll ealled upon Horth Korea to coase hostilities, but the latter lgnored the order and continued to press the attack.

Were the members of the United Nations to stand $1 \mathrm{~d} I \mathrm{y}$ by wh1le South Korea was devastated by the Horth Korean attaek? According to the Charter, the Securlty Couno1l vould be expeoted to take action to stop the attack. But the apecial military egrooment necessary for it to take enforcement action had not boen made. This caused the milltary sanction clauses of Chapter VII to become lnoperative, and honce of no assiatance. Next, one would expect, from the Charter, that Artiele 106 (Transitional Socurity Arrangemonts) would apply. Elero again the cleuse beomo inoperative, alnce Russia rerused to assiat in joint action. 
sine the explicit provislons of the Cherter for onforcement moasures bocame Inoperative, the Security Counc1l resorted to the Improvisations necessary to make the Charter effective. It attompted to follor the procedure outlined in the Charter as fully as, possible by having the securlty 1

Councll recommend anction, and, later, Onifled Comand whloh would make reports to the Socurity. Counc11. Tho nations at San Prancisco had algned a treaty which guaranteod, thols "offective collective measures for the prevention and ramoral of throats to the poace, and for, the suppreasion of acts of aggression or ather breaches of the peces." Certalnif, the algatorles had a right to rely on that guarantes and to construe the Charter in a manner which would make it offoctive in time of need. Any other course would have allowed an indopendent nation to fall the viotim of armod attack and would have rendered the Charter inoffective in porforming its fundamental stated task.

It should be noted that the term "recompond" is used here in its customary sense, rather than in the spocialized sense discussed in conneotion with Artlele 39 of the charter. 


\section{CHAPTER VIII}

\section{GOHCLUSTOH:}

Military Pressure Might Be Necessary in Order to Implement a polloy of Collective Security

What is the Lgnifleance of the Koraen ection for the development of the Americen polley of collective security through the Untted Nations? In the I1rat place, it has demonatrated that the offectiveness of polley of collective security at the present stage, in world afralrs may depend

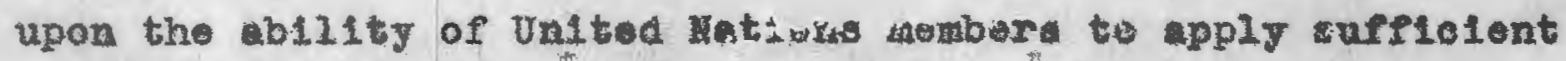
prossure agalnst those who throaten the security of the mombers. The Korean action hes been the Iret occasion in wieh the United States has folt it necessary to latilize armed atght on the fleld of battle in order to lmplement a polley of collective security through the United rations.

\section{D1stinctlons Between the Korean Action and Prevlous Questions considered by the Security Coune11}

The use of nilltary force by the United States and other nations in order to implement a resolution of the Security Councll (the June of Resolution) has served to distingulah this case from previous ones consldered by the Security Counc1l. At the time of writing, the Korean problem is at111 in a stage at which the milltary pressures have not been reduced to the polnt where deliberatlons can proeed 


$$
-101 .
$$

in the more favorable atmosphere, freor of tension, that had been advocated so strongly in the pre-korosn polloy of the United States. The pro-korean polley of the United Staten emphasized the nocessity of roducing the allitary preasure In the area of a dispute in order that the parties might arrive at lasting political settlement. The Korean problem 1. at1II in a stage where the military pressure interferea - Ith political settlement; hence any comparison of Amerisen polley with regard to collective security as expressed in the Korean action and the American polley in proviou Instanees id abject to the I1mitations lmposed by these apecial circunstancos.

The despatch of arred assistance to the Republio of Korea by the United Statos oven before the explicit approvel of such assistance by the Seeurity Counc1I has precedent In the position taken by this country with regerd to the 1 Greek case. Although the Dnited States ald not como to tho point of sending lerge seale military assistance to Greece in 1947, It did insist that it had a right to do so, oven If the Sovlet Union should cast a nogative vote. The United States besed its view in the Groek case on the right of statos to act individually or collectively in order to prowote the general purposes and prinolples of the onfted Intions in the face of a threat to the peaco. It maintained that obstrue $10 \mathrm{n}$ in the Seourlty Cound $11 \mathrm{by}$ a permanont 


$$
-102
$$

mamber eoula not be used to prevent action based on Article 51 of the Chartor, which allows for individual or pollective self-derense against an armed attack "unt11 tho soourity Cound1, hat taken the messure nocesgary to maintain International peace and cocumity." In the Greek case it apparentiy was relt by the United State that the altuation was not of such an extreme nature as to noeossitate armed assistence to Greece. In the irorean case it 1s obvious that the united States ragurded the altuation as so acute that Inmediate ml1tury ald was nocessary. It is intoresting to note that, so far as poliey is concerned, the Amerioan action In Korea was cetulily $10 s$ extremo than that proposed in the Greek oase. In the Grok case, the Unltod States wont so far as to assert the right to set aside the negative roto of a pormanent momer in onder to achieve colleatlve seourity under the Cnerter of the United Natlons. There was no veto in the Koreen case.

The persistent efforts of the United States to dove2op. a pelloy of colioctive security through the Unlted Nations have caused it to derelop an interpyotation of Artiele 51 of the Charter that would serve to angwer these neods-me the Counell thould be unable to take ection in Its own right. The Berlin case provlded another opportunlty for the Jnited States to announce position with regard to coljective security that was in a milar vein to that pronomoed in the Greek case. 
In the Berin case, Article 51 of the Charter vas apeelfically named as justifying the repulsion of armed attack by the use of armed counter-attack.

Thus way oonclude that the Amerlean polley of colleotive security through tho Enltod setions could be based on the rlght of menbers to repel armed attaok through indivun or colletive armed measures-as long as the cotlows taken were In accoraance with the general purposes and prinelples of the Unlted Nations." As we haw teon, this poliog hal been announced on several occations prior to the Korean cotlot the latter luply carried it out to 1 to logtcal concludono- tho actual sending of axmod asiotence to nation which had beon attacked.

In the Korean case the United states has developed an interpretation of Apticle 2 of the Charter to supplement Its former policy develops around Axticle 51, and in adaltion has lieunched the "Untting for Poec" resolutlon as a new Intergretation of the Charter. Although the valting for Pase" resolution 1s product of the Korean action, as a now Interpretation of the oharter. It is still in the proees of abvelopment. Thus it is a pose1ble balls for futrure action rather that a means by which the prinelple of collective socurity has been Implomented th the troroun case.

\section{The Unanimity Principle and Security Coune11 Act10}

At the tine the Charter was drafted the Second Forld Whar was still in progress, and the successful conclesion of 
that war necessitated the unity of the great powers. This necessity, in eddition to the previous experience of successful unlty during the war among the great powers, gave the great powers confidence in their ability to. work together toward a common goal. It was only natural, in drafting an instrumont for the preservation of peace in the post-wer years, that the great powers should desire to continue successful alliance then in sight of Its goal of complete defeat of Germany and Japan. If the unity of the great powers could provide a means whereby the greatest aggressor nations in the twentieth century could be subdued, truly, such comblnation mlght be valuable as the foundation for lasting peace. Unfortunately, a very important factor overlooked in incorporating the premise of unity into the United Nations Charter. The clreumstances under whlch this unity had been achleved wore those of war. In war national interests not directly related to winning the war tend to be subordinated to a comon goal. But the Charter was supposed to servo in time of peace, when conflicting national interests, no longer kept submerged out of respect for the common alm of defonding national independence, were quite likely to make themselves felt.

The Efforts of the United States to Increase the Powers of the General Assembly

The difficultios in obtalning unanimity among the great powers in the Securtty Councll have led the United States to press for greater and greater extensions of authority to the General Aaembly in security matters. The Korean case 
1. outstanding in demonstrating the degree to which the Unt tod States has como to accept many of the views expressed carlier by the leaser powers.

At san Francisco, in the comitte assigned to discuss the relation of the General Aasombly to the Security Counoll on enfercement matters, the Now Zealand delegate had proposed expanded powers for the Ceneral Amembiy. The Now Zoaland poltion embodied the viehs of many of the middie-alzed and smell powers in an ariendment which proposed: "That this committeo express Its approval of the plan that in all mattors of the application of sanctions, milltary or economic, the

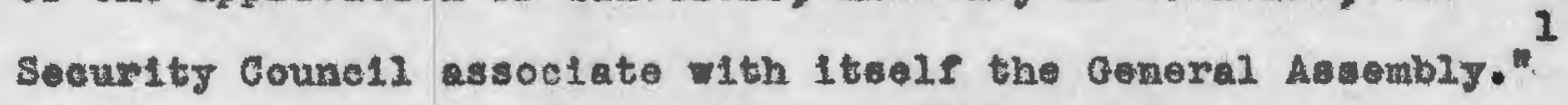
At that time the delegate of the United states had expressed sympathy wth the Now zealand polnt of view, but had alsagread with the coneluelons reached. The American dologate stated that, given councll which was froo to act,

- It would not be nocessary to send anyone's sons to di again. The council, in continuous session would reach into situations which threatened the peace as as to prevent another world war. He pleaded that the Coumitte should not weaken the councll'a powers by requesting "volee" for the smaller nations, to the extent that the volice would be heard only in fighting a war, but not in keepling the peace.

The American delegate concluded his remarks by expressing the vlew that "1t was Inconcelvable that any action of the council would be contrary to the wiohos of a majorty of the Assembly." p. 286.

$$
\text { U.N. Conf. Intrit Org., Vol. 18, Comanlssion III, }
$$

8 Ib1d. 
And again, at a later meeting, the American delegate reiterated his plea "that the Comaltoe preserve the Councll as the vital agency to prevent aggress1on." In arguing against the New Zealand proposals the American delegate was most emphatic in his demand for the principle of unified action by the permanent members:

- For the proper balance, he sald, the Counc1l must have strong executive authority; whoreas, the democrat ic Assembly would assure every member an equal vote. If the New Zorland amendment wore adopted, the Assombly would encrosch upon the Council's powers. The Council, he sald, would be a representative body of the Assombly, just as the Assembly would be representative of the varlous countries, I

By the fall of 1950, the United States had decided. that it could no longer place the trust in the unenimity princ1ple that it had expressed at San Francisco. On September 20, 1950, Secretary Acheson announced the now Amorican policy. He stated:

One of the fundamental purposes of the United Nations, expressed in Article 1 of the Charter, is that 1t shall take effective collective measures for the prevention and removal of threats to the peace, and for the suppression of acts of aggression or other breachos of peace."

The action of the Unted Nations to put down the aggression which began on 25 June ggainst the Republic of Korea was exactly the ffective collective measure which was required. It marked a turning point in history, for it showed the way to an onforceablo rule of law anong nations.

The world now waits to see whether wo can bulld on the start we have made. The United Nations must move forward energetically to develop a more adequate system of collective security, for if it does not move forward it 111 movo back.

\footnotetext{
p. 316.

U.N. Conf. Intnt1 Org., Vol. 12, Commission III,
} 
Article 24 of the Charter gives the Security Couneli primaxy responsibility for the milntennne of perce; and thls is the wey it should be. But if the Security council Is not able to act because of the obstruetive tactice of a permanent menber, tho Charter does' not leave the United Natlons lapotent. The obligation of all Members to tale cetion to maintain or restore the peace does not disappear becaus of veto. The Charter, in Artieles 10,11, and 14, also vests in tho Genoral Atsombiy authority and responsibility for matters affecting internotional peaco. Tho General Assembly can and hould organize itaelf to discharge 1tg responsib1lity prompty and dectalvely if the Security Councll is prevented from acting.

Acheson's proposal: were developed in the first

Commlttee by John Foster Dallee, who presented the Amerloan vlews with V1gor. Holaing that the seourity Council ald not have exolusive powers in the reintenance of poace, ho outilnod an interpretation of the Charter which would give greater powers to the General Assembly:

But the Charter, which gavo the Security Counc12 "primary respoasiblifty" for peace and which anctloned the veto, also gave the Coneral Assembly the right to make recomendations oven in cases where the right of veto could be exercised. Apart from Articles 11 and 14, Article 10 gave the Asambly the right to make recommondations to the Herabers on any matters within the scope of the present Charter" except in relation to disputos or situations with which the Security Councll was dealing.

In fact, at San Francisoo tho amall Powers had only agreed to the porer of veto on condition that the General Assembiy were grented the power to Intervene and to make recommendetions within the Iramework of Chapters VI and VII of the Charter in cases where the Secur1ty Councli was unable to discharge 1 ts primary responelbility. As the delegation of the J.8.S.R. had objected to the Genoral Assembiy having the High to overrul voto, even by way of a recommendation, the Dnited States had adviead the Sorlet Union on 18 June 1945, that, in vies of the short time wioh remalned before the cerremony of $81 \mathrm{gning}$ the Charter, the United States could walt no longer and that, in order to brok the deadoek, it was goling to nogotiate

\section{1}

U.N.O.A." Off. Rec., Plenary Hedting, Verbat Im Record of Neetings, VoI. I, 19 September-15 December 1950, (279th 粠e ting, 20 September 1950), p. 84 . 
alone with the small fowers. The following day, the Chalrmen of the Soviet Inion delegation had informed the Secretary of state that his Government asroed to the extension of the scope of Article 10. The tine had now come to use the right obtained thet day.

Section A of draft resolution A.C. $1 / 576$ provided that the Ceneral Assembly could promptly make a recommendation if Security Council setion mere blocked. Obviously, recommendation by the Coneral Assembly had not the force of a decision of the security council taken under the terms of Chapter VII of the Charter. But the histroy of the Korean question had shown that the voluntary response to a recommendation could be oven more effective than obedience to an orders although the Security Councll had not exereised its powers of action, 1 fifty-three Henbers were carrying out its recomendation.

These proposals embodied the very princlple which the United States had opposed at San Francisco--particlpation of the General Assembly in enforcoment moasures-and went a long way toward remedying the weaknesses of the unanimity principle. After much debato in the First committee and in the Plenary meetings, the proposals (with some amendments) ware adopted on November 3,1950 , by the overwhelming majority of 52 votes 2 to 5, with 2 abstentions. The measures adopted were grouped together under the title "Uniting for Peace." This resolution delegated much of the prerogative of the Security counc1l to the General Assembly in the event that the former should be unable to act. Some of the possibilities for future development under the "Uniting for Peace" resolution may be appreciated by a study of the followlng paragraph:

1. Resolves that if the Securlty Councll because of lack of unanimity of the permanent members fails to exercise

U.N.G.A. off. Rec., First Committee, Summary Fecords, 20 September-18 December 1950, 354th Heeting, 9 october 1950, p. 64.

2

Ibld., 5th Session, Plenary Heetings, Vol I, 19 September-15 Decomber 1950, p. 347. 
Its primary responsibility for the maintenance of international peace and security in any case where there appears to be a threat to the peece, bresoh of the peace, or act of aggression, the General Assembly shall consider the matter immodiately with a view to making appropriate rocommendations to sembers for ooliective measures, including in the case of a breach of the peace or act of aggression the use of amed force whon nocessary, to maintain or restore international peace and security. If not in session at the time, tho General Assembiy may meot in omergenoy special session within twenty-four hours of the request therefor. Such emergency special session shall be called if requested by the security Council on the vote of any seten members, or by a majority of the Hembers of the United Nations.

A study of the Charter and its explicit provisions for the control of enforcenent measures leads one to the concluslons thet this rosolution is in offoct an extensive supplement to the charter. Indeed, it would appear to be a now interpretation of the Charter. The rosolution has brought up many questions of international law. As an expression of the Amerioan policy of collective security through the United Nations, it marks definite departure from the stand taken by the United States at San Francisco.

$\frac{\text { The Korean Action a a Focal Point for }}{\frac{\text { the Formulation of an Effective }}{\text { polley of Collectlye security }}}$

At the time of writing, an armistice has not as yot been signed in the Korean war, and there are no definite in-

I U.N.G.A. Orf. Rec., 5th Session, Supplement 20, Fesolutions adopted by the General Assembly during the period 19 September-15 Decerber 1950, p. 10. 2

For discussion of somo abpects both logal and political of this resolution see I. H. Woolsey's interprotation in the A.J.I.L., VoI. 45, 1951, pp. 129-137. 


$$
-110
$$

Indications of the final terms of settlement. Any surver of the Korean probler, consequently, is Ilmited by the ract thet the problem has not been fully solved. Several observations can be made, however.

The Koraan sotion has narked the flrst application of military enforcoment measures through the United Nations. As such it has demonatrated the w111 of the bujk of the nations of the world to dezolop an effective program of collective seourlty for thoir mutual proservation and fox halting armed expansion at its source. In this program the United stated has taken the load in moeting force with foreo. In a Ineere attempt to replace the rule of force with the rulo of lav in International relations. The experionoes gained In the Korean action meg serve as a focal polnt from which the American poliey of collective securlty through the United Nations can be developed into a more offective guaranty of world harmony. 


\section{ACKNOWLFDONENT}

The writer is greatly indebted to Dr. Daniel H. Thoms, Head of the Department of HIstory and Pollt1ca1 Sclence, and to Hr. Benfemin NImer for thelr valuable suggestions. Throughout the jear, their pet1ence and understanding he been of great assistance in the ondeavor to 1ocate and evaluate fundemental source material In a field noted for 1 ts complexity. The writer also wishes to thenk Hr. F. P. A IIen, University ILbrarian, and his staff for the courteous asistance they have rendered in obtaining material. 


\section{BIBLTOGRA PEX.}

\section{Booke}

Benns, F. Loo. Burope S1noe 2914 in 1 to porld Sett1ng. 7th ed. New Tork, 1948.

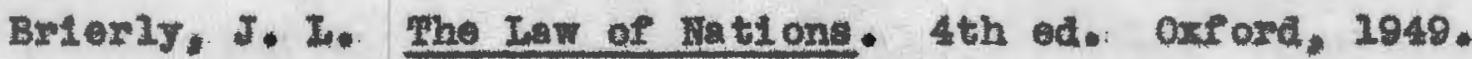
Br1gge, Herbert W. The Iam of Het1 one. Hew York, 2938. - The Lar of NatLons. 2d od. New Yoxk, 1952.

Chase. Bugene P. United Mations in Aetion. Now Yoxk. 1050. Harley, J. Eugene. Dooumentary Textbook on the United Yattone. Los Angeles, Callfornin, 2950. Ianice, Harold R. (ed.) Her Grele in Aala. Hew York, 1947. Langer, W1111am Is: An Enerclopedia of Worla Hetory. Boston, 2848 .

Helson, $\mathrm{F}$. Prederlok. Kore and the old onders in Aste. Baton Rouge, ta , 1946.

Nus abaun, Arthur. A conclee Hatory of the Iaw of listions. New. York, 1950.

\section{Pertodies ls}

Hing. Yuen-IL. "Reoognttion by the Untted Nations of the Representetion of Member states Criteria and Prooedure."Americen Journal of Internatione 1 Iar. Vol. 45 (1952), 704.

New York Mimes, 1050. 


\section{Public Documents}

Cherter of the United tions.

Unt ted Pations Conference on International Orgenization.

Documents. Now Tork, 1945.

United Hations of Plelal Records of the General Assemb2y.

Now Tork and Par18, 1947-1951.

Untted Nations, Secretarlat. Researoh Seetion. Mackground Papera," Ho. 62 (18 may 1950).

United Hatlons Secur1ty Counc1l offlolal Records. New York, $1946-1951$.

U. S. Department of State. Korea 1945 to 2948. Pub. 5305. Wa shingt on, 1948.

- United States Relations with Chine. Pub. 3573.

Washington, 1949.

U.S.S.R. Responds to Requests for Mediation.

Vo1. XXIII, Ho. 570. Mashington, 2950. 